

\section{Sumário}

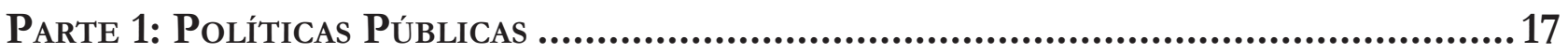

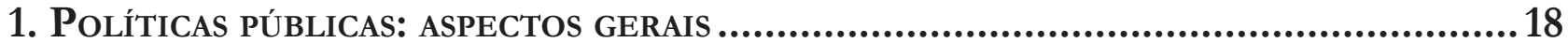

UM MODELO POLÍTICO DE IMPLEMENTAÇÃO PARA AS POLÍTICAS PÚBLICAS: OS PAPÉIS DO DIREITO E DOS JURISTAS.

William H. Clune III

Evaluación de las obras públicas en gobiernos locales en MÉxico: Desafíos de LaS POLÍTICAS PÚBLICAS DE PARTICIPACIÓN CIUDADANA

Louis Valentin Mballa e Arturo Bermúdez Lara

Paternalismo libertário e políticas públicas: intervenção e transparênCia

Marcia Carla Pereira Ribeiro e Victor Hugo Domingues

2. Políticas públicas E COVID-19

LiMITES E POSSIBILIDADES PARA O USO SECUNDÁRIO DE DADOS PESSOAIS NO PODER PÚBLICO: LIÇÕES DA PANDEMIA.

Miriam Wimmer

EFICIÊNCIA DAS POLÍTICAS DE INOVAÇÃO NOS SETORES INDUSTRIAIS BRASILEIROS: SUGESTÕES PARA A CRISE DA COVID-19

Michelle Márcia Viana Martins e Chrystian Soares Mendes

CoMPLIANCE EM TEMPOS DE CALAMIDADE PÚbLICA: ANÁLISE SOBRE A FLEXIBILIZAÇÃo DA TRANSPARÊNCIA DE DADOS E INFORMAÇÕES DURANTE O ENFRENTAMENTO DA COVID-19 NO BrasiL

Luciana Cristina da Conceição Lima, Alcindo Fernandes Gonçalves, Fernando Cardoso Fernandes Rei e Cláudio Benevenuto de Campos Lima

3. Políticas públicas e accountability

ACCOUNTABility E DESENHO INSTITUCIONAL: UM “PONTO CEGO" NO DIREITO PÚBLICO BRASILEIRO

Danielle Hanna Rached

ESTRATÉGIAS REGULATÓRIAS DE COMBATE À CORRUPÇÃo 
O controle e a avaliação pelo Tribunal de Contas da União das políticas públicas IMPLEMENTADAS POR DESONERAÇÕES TRIBUTÁRIAS NO BRASIL

Vinicius Garcia e Carlos Araújo Leonetti

4. Políticas públicas em Matéria de SAÚde

A livre opÇão pela Cesariana: um "NUdge Às aVessas". .268

Bruna Menezes Gomes da Silva e Júlio Cesar de Aguiar

AUTISMO: ASPECTOS JURÍDICOS DA ACESSIBILIDADE E RESPEITO

Fabiana Barrocas Alves Farah e Danilo Fontenele Sampaio Cunha

SAÚdE E DOENÇAS RARAS: ANÁLISE DA JUDICIALIZAÇÃo DO ACESSO AO TRATAMENTO E SUAS LIMITAÇÕES.

Danilo Henrique Nunes e Lucas de Souza Lehfeld

5. OUTRAS POLÍTICAS PÚBLICAS EM ESPÉCIE

REGUlAÇÃO DAS ÁGUAS: UMA ANÁLISE EMPÍRICA DA PRODUÇÃo NORMATIVA DOS ÓRGÃOS REGULADORES FEDERAIS

Bianca Borges Medeiros Pavão, Natasha Schmitt Caccia Salinas e Thauany do Nascimento Vigar

“LET THE ALGORITHM DECIDE": IS HUMAN DIGNITY AT STAKE?.

Marcela Mattiuzzo

DAS ACEPÇÕES DOS DIREITOS DOS REFUGIADOS ÀS VOZES SILENCIADAS NAS POLÍTICAS PÚBLICAs371 Thaís Araújo Dias e Monica Mota Tassigny

Planejamento familiar: “inimigo" a Ser combatido, “aliado” libertador ou falso "AMIGO"?

Vinicius Ferreira Baptista

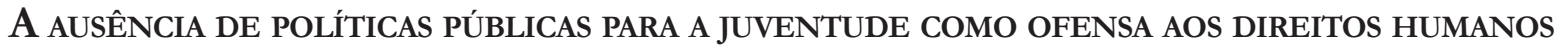
William Timóteo e llzver de Matos Oliveira

AnÁlise CÊniCa dos feminicídios em Curitiba: propostas preventivas e repressivas ....433 Ticiane Louise Santana Pereira, Octahydes Ballan Junior e Antonio Henrique Graciano Suxberger

ORIGIN AND CONSEQUENCES OF THE WAR ON DRUGS. FROM THE UNITED STATES TO ANDEAN COUNTRIES

Silvio Cuneo e Nicolás Oxman 
Trabalho Decente: comportamento Ético, política pública ou Bem JuRIDiCamente TUTELADO?.

Silvio Beltramelli Neto e Mônica Nogueira Rodrigues

El FINAL DE UNA POLÍtica PÚBLICA: ANÁLISIS DEL CICLO POLÍTICO DEL PROYECTO DESTINOS INDUCTORES PARA EL DESARROLLO TURISTICO REGIONAL (DIDTR) - BRASIL. .496

María Belén Zambrano Pontón, Magnus Luiz Emmendoerfer e Suely de Fátima Ramos Silveira

Alternativa tecnológica para COMPensaÇão de CRÉditos de ICMS: ESTUdo de Caso da VIABILIDADE DO USO DE DLT EM NOTA FISCAL ELETRÔNICA .520

Danielle Mendes Thame Denny, Roberto Ferreira Paulo e Fernando Crespo Queiroz Neves

Parte 2: Temas Gerais

A construção do Direito Humano ao Alimento no plano internacional. 551 Tatiana de A. F. R. Cardoso Squeff

Grupos vUlNERABles de ESPECIAL PROTECCIÓN POR PARTE DEL INSTITUTO NACIONAL DE Derechos Humanos (INDH) ¿EN QUIÉN PODRÍA Y DEBERÍA ENFOCARSE EN BASE A LA DOCTRINA Y A LA EXPERIENCIA COMPARADA IBEROAMERICANA?

Juan Pablo Díaz Fuenzalida

El SUFRAGIO ELECTRÓNICO COMO ALTERNATIVA AL SUFRAGIO TRADICIONAL: LUCES Y SOMBRAS DE UN DEBATE RECURRENTE 595

David Almagro Castro, Felipe Ignacio Paredes Paredes e Edgardo Lito Andres Cancino

Cognoscibilidade E CONTROLE SOCIAL dA TRANSPARÊNCIA PÚbliCA SOB A ÉGIDE DA DEMODIVERSIDADE: ESTUDO EMPÍRICO DE PORTAIS ELETRÔNICOS MINISTERIAIS LATINOAMERICANOS

Ana Carolina Campara Verdum, Leonardo Fontana Trevisan e Rosane Leal da Silva

DESAFIOS E BENEFÍCIOS DA INTELIGÊNCIA ARTIFICIAL PARA O DIREITO DO CONSUMIDOR 655 Sthéfano Bruno Santos Divino

QUEM TEM MEDO DA RESPONSABILIZAÇÃo SUBJETIVA? As TEORIAS DA CONDUTA E DA IMPUTAÇÃO, PARA UM DIREITO ADMINISTRATIVO SANCIONADOR CONSTITUCIONALIZADO...........................690 Sandro Lúcio Dezan e Paulo Afonso Cavichioli Carmona

A INSUfiCiÊNCIA dE TRIBUTAÇÃo COMO FUNDAMENTO PARA O AFASTAMENTO DA RESERVA DO POSSÍVEL NA GARANTIA DO MÍNIMO EXISTENCIAL E DA DIGNIDADE HUMANA. 711 Dione J. Wasilewski e Emerson Gabardo 


\title{
Trabalho Decente: comportamento ético, política pública ou bem juridicamente tutelado?*
}

\section{Decent Work: ethical behavior, public policy or legally protected asset?}

\author{
Silvio Beltramelli Neto** \\ Mônica Nogueira Rodrigues***
}

\section{Resumo}

Pretende-se contribuir com a compreensão da natureza do Trabalho Decente, com base na seguinte indagação: o Trabalho Decente é comportamento ético, política pública ou bem juridicamente tutelado? O problema de pesquisa foi enfrentando unicamente a partir do pensamento do economista e filósofo Amartya Sen, admitido inspirador da concepção em apreço. Em conclusão, propõe-se que a natureza do Trabalho Decente é multidimensional e que, agregando a pretensão a um comportamento ético, a políticas públicas e à tutela jurídica, lança-se a promover o Desenvolvimento Humano, tal como idealizado por Sen, no campo das relações laborais. Empregou-se o método dedutivo de abordagem e bibliográfico de procedimento, com destaque para o exame analítico de documentos oficiais produzidos pela Organização Internacional do Trabalho e pelo Programa das Nações Unidas para o Desenvolvimento.

* Recebido em 29/04/2020 Aprovado em 28/10/2020

** Professor Titular da Pontifícia Universidade Católica de Campinas (PUC-Campinas), Centro de Ciências Humanas e Sociais Aplicadas, Faculdade de Direito, vinculado ao Programa de PósGraduação Stricto Sensu em Direito, integrante da linha de pesquisa "Cooperação Internacional e Direitos Humanos" e do Grupo de Pesquisa "Direito num Mundo Globalizado. Pós-doutorado em Desenvolvimento Econômico pelo Instituto de Economia da Universidade Estadual de Campinas - Centro de Estudos Sindicais e de Economia do Trabalho (UNICAMP/IE/ CESIT). Doutor em Direito pela Universidade de São Paulo (USP).

E-mail: silviobeltramelli@puc-campinas.edu.br.

***Mestranda no Programa de Pós-graduação em Direito da PUC-Campinas, na linha de pesquisa Cooperação Internacional e Direitos humanos. Bolsista Capes (PROSUC II). Membro do grupo de pesquisa "Direito num mundo globalizado" (CNPq/PUC Campinas). Coordenadora do subgrupo ICSID/CPA do Núcleo de Estudos em Tribunais Internacionais da USP. E-mail: monica.nogueira.rodrigues@gmail.com.
Palavras-chave: Direitos Humanos. Cooperação Internacional. Trabalho Decente. Amartya Sen. Desenvolvimento Humano.

\section{Abstract}

This study intends to contribute to Decent Work nature comprehension stem from the following inquiry: Is the Decent Work an ethical behavior, a public policy or a right protected by law? This research problem was worked only by thoughts of the economist and philosopher Amartya Sen, who inspirited the concept of Decent Work. In conclusion it is proposed that Decent Work nature is multidimensional and the claim can be combined with a ethical behavior, a public policy and a right protected by law to promote Human Development as it was idealized by Amartya Sen in labour relation sphrere. The deductive approach method and the bibliographic procedure method were used, with special focus to analytic exam of documents issued by International Labour Organization and United Nations Development Programme.

Keywords: Human Rights. International Cooperation. Decent Work. Amartya Sen. Human Development. 


\section{Introdução}

Adotada, em 1999, pela Organização Internacional do Trabalho (OIT) como eixo central de suas ações para o século XXI, a concepção de Trabalho Decente, conquanto tenha conquistado ampla difusão nos espaços de governança global e cooperação internacional, bem como tenha galgado reconhecimento nas searas nacionais de análise e deliberação, ainda desperta dúvidas sobre seu conteúdo e alcance, bem como sobre sua natureza.

A literatura brasileira pode ser encarada como uma boa ilustração desse déficit analítico, na medida em que se divide entre menções ao Trabalho Decente como algo pressuposto e amplamente elucidado em termos de conteúdo (o que não procede), análises críticas e refutadoras de sua pertinência e conceituações personalíssimas.

Ainda desde a realidade brasileira, é crível imaginar que a falta de consenso e mesmo de clareza quanto à concepção de Trabalho Decente e suas finalidades corroboram a ausência de penetração da ideia nos espaços deliberativo da Administração Pública, legislativo do Parlamento, jurisdicional do Poder Judiciário e, por conseguinte, aprofunda a falta de efetividade na sua promoção.

Assim, este estudo pretende contribuir com a compreensão da natureza do Trabalho Decente, com base na indagação lançada em seu título, enfrentando-a, unicamente, a partir do pensamento do economista e filósofo Amartya Sen, admitido inspirador da concepção em apreço.

Para tanto, empregar-se-á o método dedutivo de abordagem e bibliográfico de procedimento, com destaque para o exame analítico de documentos oficiais produzidos pela OIT e pelo Programa das Nações Unidas para o Desenvolvimento (PNUD).

\section{0 advento da concepção do Trabalho Decente segundo a OIT: contexto e pretensões}

A concepção de Trabalho Decente não pode ser adequadamente compreendida de modo desconectado das circunstâncias que marcam o percurso histórico da OIT e de suas ações.

Criada em 1919, a OIT é habitualmente reconhecida como uma estrutura internacional inovadora em sua arquitetura institucional tripartite (Estados, representantes de trabalhadores e representantes patronais), pretensamente voltada à promoção da justiça social, por meio de seu mandato orientado para a produção supranacional de um corpo normativo constituinte do direito internacional do trabalho, tendo se tornado criadora de tendências não apenas em relação às configurações que utiliza para formular próprias convenções e recomendações como também cooperação técnica e expertise internacional em questões trabalhistas. ${ }^{1}$ A OIT sempre acompanhou e interferiu nas dinâmicas de transformação do capitalismo, trazendo contrapontos (no campo da regulação e não da emancipação) para a afirmação de um modelo com base no qual poderia se regular o mundo laboral, desde um alegado propósito de justiça social.

Não obstante, durante quase todo o século XX, os historiadores do trabalho não deram muita atenção a recortes internacionais como referência, não havendo muito interesse no estabelecimento de conexões, comparações e relações internacionais. Nesse cenário, a OIT e sua atuação primordiamente passiva — ou seja, apostando na adesão estatal espontânea a convenções e recomendações — eram constantemente negligenciadas, nas searas nacionais. Entretanto, ao final da Guerra Fria, os Estados-nação começaram interessar-se mais pela coordenação de políticas internacionais por instituições internacionais; o interesse de pesquisa

VAN DAELE, Jasmien. The International Labour Organization (ILO) in past and present research. International Review of Social History, Cambridge, v. 53, n. 3, p. 485-511, dez. 2008. p. 486. 
na OIT direcionou-se à transnacionalização da história do trabalho como campo de estudo. ${ }^{2}$

Em torno das constantes transformações que aconteceram, em âmbito internacional, acerca da proteção dos direitos humanos do trabalho, destacam-se duas correntes atinentes ao papel do Estado quanto ao tema. A primeira advoga o enfrentamento do problema do desemprego e da exclusão social com uma atuação estatal intervencionista. Já a segunda propugna pela ampliação da autonomia dos particulares, desregulamentação e flexibilização de relações de trabalho. Entre as correntes, há de comum, apenas, a certeza da atualidade da discussão sobre a exclusão social e desemprego enquanto piores desafios hodiernos, no campo laboral ${ }^{3}$. Observados mundialmente, tais desafios, por serem economicamente condicionados em tempos de capital globalizado e financeirizado, descortinam a incapacidade dos sistemas internacionais de proteção dos direitos humanos de conduzirem os Estados a atender aos desígnios de combate à desiguldade social, sobretudo pela via da adesão voluntária e consentimento expresso a convenções internacionais, exatamente o meio de ação mais privilegiado pela OIT. ${ }^{4}$

Diante dessas dificuldades, a OIT viu-se premida ao encontro de novas estratégias de atuação, mais pró-ativas e com a consideração das vicissitudes de cada país quanto a seus problemas e limitações para resolvê-los.

Com tal propósito, o Diretor-Geral da OIT apresenta, em 1999, a 87ª Conferência Internacional do Trabalho (reunião em Assembleia de todos os Estados- Membros), a concepção de Trabalho Decente e a sua difusão mediante estratégia denominada "enfoque integrado", que compreenderia a disseminação da promoção do Trabalho Decente às demais instituições internacionais de direitos humanos e de cunho político-econômico, conjuntamente a ações de cooperação técnico-jurídica e aos Estados, com a finalidade de construir Programas de Trabalho Decente específicos para cada país. ${ }^{5}$

O próprio conteúdo da concepção de Trabalho Decente sofreu alterações e influxos conceituais, desde sua adoção. Uma detida análise documental das atas registrais das discussões travadas a respeito do assunto, em todas as Conferências Internacionais do Trabalho, desde 1999, evidencia uma proposital ausência de definição precisa do Trabalho Decente e de determinação de um possível caráter universal de seu conteúdo, contrapondo-se a um consenso institucional no sentido de tratar-se de um conteúdo sujeito a vicissitudes nacionais e que deve ser compreendido sobretudo com base nos objetivos estratégicos enunciados como instrumentos de sua consecução ${ }^{6}$. Esses, de fato, precisamente delimitados desde a origem da ideia.

A promoção do Trabalho Decente concatena, pois, quatro objetivos estratégicos: proteção dos direitos humanos das relações de trabalho, geração de empregos de qualidade, ampliação da proteção social e fomento do diálogo social ${ }^{7}$.

O primeiro objetivo estratégico é constituído de três prioridades ${ }^{8}$ : promoção da Declaração da OIT

2 VAN DAELE, Jasmien. The International Labour Organization (ILO) in past and present research. International Review of Social History, Cambridge, v. 53, n. 3, p. 485-511, dez. 2008. p. 510.

3 MACHADO, Raimar Rodrigues. O trabalho humano frente à ideia de liberdade. In: COSTA, M. M.; LEAL, M. C. H. (orgs.). Direitos sociais e políticas púbicas: desafios contemporâneos. Santa Cruz do Sul: EDUNISC, 2012. p. 204-280.

4 MORAES, M.; DIEHL, R. O papel da organização internacional do trabalho na promoção do trabalho decente: diálogos com Amartya Sen. Revista Prolegómenos Derechos y Valores, Bogotá, v. 19, n. 38, p. 97-108, jul./dez. 2016. p. 98.

5 OIT. História da OIT. Disponível em: http://www.oitbrasil.org.br/content/hist\%C3\%B3ria. Acesso em: 29 out.2019.

6 BELTRAMELLI NETO, Silvio; VOLTANI, Julia de Carvalho. Investigação histórica do conteúdo da concepção de Trabalho Decente no âmbito da OIT e uma análise de sua justiciabilidade. Revista de Direito Internacional, Brasília, v. 16, n. 1, p. 166-185, 2019. p. 173.

7 Esses quatro objetivos estratégicos estão descritos, cada qual em detalhes, no documento oficial de apresentação da concepção: ORGANIZACIÓN INTERNACIONAL DEL TRABAJO. Conferencia Internacional del Trabajo. 87a reúnion. Memoria Del Director General: Trabajo Decente. Oficina Internacional del Trabajo, Ginebra, jun. 1999. p. 14. Disponível em: http://www.ilo.org/ public/spanish/standards/relm/ilc/ilc87/rep-i.htm. Acesso em: 05 jan. 2019.

8 ORGANIZACIÓN INTERNACIONAL DEL TRABAJO. Conferencia Internacional del Trabajo. $87^{a}$ reúnion. Memoria Del Director General: Trabajo Decente. Oficina Internacional del Trabajo, Ginebra, jun. 1999. p. 14. Disponível em: http://www.ilo.org/ public/spanish/standards/relm/ilc/ilc87/rep-i.htm. Acesso em: 05 jan. 2019. 
sobre Princípios e Direitos Fundamentais no Trabalho de $1998^{9}$, intensificação da luta contra o trabalho infantil e renovação das atividades relativas às normas da OIT, todas com o desígnio de preservar os princípios e direitos do trabalho. O segundo objetivo instiga a geração de empregos de qualidade, ou seja, dignos, remunerados, sem distinção de sexos, com a proteção necessária e com igualdade de condições de ingresso. O terceiro objetivo estratégico mira a salvaguarda pelo Estado daqueles que, permanente ou transitoriamente, não têm condição de manter seu autossustento, por inaptidão para o trabalho ou em razão do desemprego, sobretudo em virtude das crises econômicas. O quarto objetivo estratégico, difusor da conformação institucional tripartite da OIT, fomenta o fortalecimento do diálogo social, enquanto sistema de deliberações consensuadas orientadas a soluções perenes.

Dentre as diversas definições que se podem encontrar nos documentos e estudos da OIT sobre Trabalho Decente, de fato, mantém-se estável a indicação de seu caráter de resultado da convergência dos citados objetivos estratégicos e de instrumento de combate à desigualdade social ${ }^{10}$.

\section{Amartya Sen: o enfoque das capacidades e o Desenvolvimento Humano}

O professor indiano de economia e filosofia em Harvard, e vencedor do Prêmio Nobel de Economia, Amartya Sen, é o artífice do marco teórico a que diz a OIT estar filiada à concepção de Trabalho Decente, tendo cabido a Sen, por essa razão, o discurso de abertura da $87^{a}$ Conferência Internacional do Trabalho de 1999, publicado na forma de artigo intitulado Work and Rights ${ }^{11}$.

O profícuo pensamento seniano é marcado pela crítica e busca de superação de premissas que protagonizam o pensamento econômico ortodoxo que prevalecera na primeira metade do século XX, notadamente no se refere às ideias de homo oeconomicus (racionalidade e comportamento humanos pautados exclusivamente pelo autointeresse), de desenvolvimento como decorrência de crescimento econômico e de separação entre ética e economia ${ }^{12}$.

Nos anos 50 e 60 do século XX, Sen dedicou-se à crítica do pressuposto segundo o qual o comportamento humano se estabelece, exclusivamente, por seu autointeresse e que tal deve pautar o pensamento e as ações econômicas. Em Sobre Ética e Economia, de 1987, o pensador indiano refuta essa ideia, para tanto resgatando o pensamento de Aristóteles ${ }^{13}$ e de Adam Smith ${ }^{14}$.

\footnotetext{
Preceitua a Declaração: “todos os Membros, ainda que não tenham ratificado as convenções aludidas, têm um compromisso derivado do fato de pertencer à Organização de respeitar, promover e tornar realidade, de boa fé e de conformidade com a Constituição, os princípios relativos aos direitos fundamentais que são objeto dessas convenções, isto é: a) a liberdade sindical e o reconhecimento efetivo do direito de negociação coletiva; b) a eliminação de todas as formas de Trabalho forçado ou obrigatório; c) a abolição efetiva do Trabalho infantil; e d) a eliminação da discriminação em matéria de emprego e ocupação". ORGANIZAÇÃO INTERNACIONAL DO TRABALHO. Declaração da OIT sobre os Princípios e Direitos Fundamentais no Trabalho. Genebra, 1998. Disponível em: http://www.ilo.org/public/english/standards/declaration/declaration_portuguese.pdf. Acesso em: 16 dez. 2019 . p. 02.

10 Paradoxalmente, é possível lançar um olhar crítico sobre a aplicação de um diálogo social em toda sua potencialidade democrática no processo de adoção pela OIT da concepção de Trabalho Decente, como aponta a reflexão presente em BELTRAMELLI NETO, Silvio; BONAMIM, Isadora Rezende; VOLTANI, Julia de Carvalho. Trabalho Decente segundo a OIT: uma concepção democrática? Análise crítica à luz da teoria do contrato social. Revista Eletrônica do Curso de Direito da UFSM, v. 14, n. 1, p. 1-36, 2019. 11 SEN, Amartya. Work and rights. International Labour Review, Genebra, v. 139, n. 2, p. 119-128, 2000.

12 Cada um desses motes mereceu um momento de dedicação e de desenvolvimento teórico por parte do pensador indiano, que, para tanto, levou a termo propostas alinhavadas desde a conjugação da filosofia e da economia política, resultantes de uma inusitada conjugação teórica entre Aristóteles, Adam Smith e Karl Marx. SANCHEZ GARRIDO, Pablo. Raíces intelectuales de Amartya Sen: Aristóteles, Adam Smith y Karl Marx. Madrid: Centro de Estudos Políticos y Constitucionales, 2008. p. 499.

13 De Aristóteles, Sen retoma a relação intrínseca entre ética, política e economia, encontrada na percepção de que a busca da riqueza, objeto do pensamento econômico, não se exaure na sua aquisição, devendo ser compreendida como meio para a consecução da sua finalidade última, qual seja, o bem do indivíduo, que também pode ser compreendido como liberdade para autorrealização ou, simplesmente, felicidade enquanto meta da existência humana (eudaimonía). SANCHEZ GARRIDO, Pablo. Raíces intelectuales de Amartya Sen: Aristóteles, Adam Smith y Karl Marx. Madrid: Centro de Estudos Políticos y Constitucionales, 2008. p. 15-18.

14 " $[. .$.$] atentar-se interiramente à irrestrita e implausível suposição do comportamento puramente interessado parece levarmos por$
} 
É a partir da associação entre a busca aristotélica da felicidade e a desmistificação do autointeresse como razão smithiana para a liberdade do mercado ${ }^{15}$, que Sen defende uma abordagem ética da economia, ademais argumentando que, conquanto seja pertinente admitir que pessoas se comportam desde seu autointeresse ${ }^{16}$, tal não pode ser uma verdade absoluta, menos ainda uma premissa de racionalidade ${ }^{17}$.

Já em um segundo momento da trajetória intelectual seniana, a década de 1970 testemunha reflexões mais específicas sobre a conceituação e a medição da pobreza e da fome, materializadas no estudo Poverty and Famines: an essay on entiltement and deprivation (1981), encomendado pela OIT e que abriga sua conclusão no sentido de que as fomes coletivas, verificadas na África, em Bagladesh e na Índia, não decorrem da escassez de alimentos, senão das imperfeições do mercado e dos sistemas sociais, em ambientes de déficit de controle democrático das ações de governo e de estruturas sociais de acesso a bens ${ }^{18}$.

Nessa quadra, na esteira das críticas ao pensamento econômico desenvolvimentista tradicional, preceituador da noção de desenvolvimento como resultante direta do crescimento econômico, aprofundam-se as contribuições de Sen ao PNUD, com destaque para a difusão da noção de Desenvolvimento Humano e para a participação na criação do Índice de Desenvolvimento Humano (IDH), com o qual se intenta oferecer uma fonte informacional alternativa ao Produto Interno Bruto (PIB) e à renda per capita enquanto dados e medições que subsidiam ações coletivas e escolhas governamentais ${ }^{19}$.

Na década de 1980, Sen volta sua atenção plena para o aprofundamento das questões filosóficas, notadamente da relação entre ética e economia, empreendendo firme contraponto, primeiro, ao que enxerga como visão positivista ou altamente tecnicista do pensamento econômico, e, posteriormente, a algumas propostas para as noções de liberdade e igualdade que ganharam destaque, sobretudo as baseadas ora em um utilitarismo revigorado e ora em um liberalismo igualitário, como é o caso das propostas de John Rawls ${ }^{20}$.

A perspectiva utilitarista ${ }^{21}$, segundo Sen, equivoca-se ao não considerar as desigualdades em relação à distribuição da felicidade, ao não atribui importância intrínseca à reivindicação de direitos, liberdades e ou-

um pretenso "atalho" que termina em um lugar diferente daquele aonde desejávamos ir. [...] Descartar toda a motivação e valoração que não sejam de autointeresse extremamente restrito é algo difícil de justificar com base na utilidade para fazer predições, além de ter uma bem duvidosa sustentação empírica". SEN, Amartya. Sobre ética e economia. São Paulo: Companhia das Letras, 1999. p. 95. Nessa trilha, são resgatadas diversas passagens do pensamento de Adam Smith que, segundo Sen, teria sido alvo de "estreitamento" pela economia moderna, sobretudo em razão da restrição do seu pensamento à liberalização do mercado, o que não seria condizente com a manifestada preocupação de Smith de que o enriquecimento derivado do livre comércio servisse, primordialmente, à eliminação da pobreza e da fome. SANCHEZ GARRIDO, Pablo. Raíces intelectuales de Amartya Sen: Aristóteles, Adam Smith y Karl Marx. Madrid: Centro de Estudos Políticos y Constitucionales, 2008. p. 44; ARAUJO, Luiz Bernardo Leite; CREDER, Fábio dos Santos. Ética, economia e justiça: a escolha social no pensamento de Sen e Smith. Dois Pontos, Curitiba, v. 10, n. 1, abr. 2013.

15 Argui Sen: "Smith opunha-se à supressão ou restrição do comércio. Mais isso não significa que ele desaprovava a ajuda aos pobres [...] nada indica que a abordagem ética smithiana das políticas governamentais teria excluído a intervenção em favor dos direitos [entitlements] dos pobres. Ainda que Smith certamente se opusesse à supressão do comércio, o fato de ele indicar o desemprego e os baixos salários reais como causas da fome sugere uma variedade de possíveis políticas públicas em resposta ao problema”. SEN, Amartya. Sobre ética e economia. São Paulo: Companhia das Letras, 1999. p. 41-42.

16 Interpretando a ideia de comportamento em Sen, diz Muniz: "o comportamento é uma questão social, o que acarreta reflexos no senso de identidade que encerra o reconhecimento dos objetivos de outras pessoas e das interdependências mútuas existentes em uma comunidade". MUNIZ, Veyzon Campos. Desenvolvimento humano sustentável e erradicação da pobreza extrema. Revista Brasileira de Politicas Públicas, Brasília, v. 6, n. 1, p. 175-191, jan./jul. 2016. Disponível em: https://www.publicacoesacademicas.uniceub.br/RBPP/article/view/3481. Acesso em: 10 mar. 2020.

17 SEN, Amartya. Sobre ética e economia. São Paulo: Companhia das Letras, 1999. p. 32.

18 SANCHEZ GARRIDO, Pablo. Raíces intelectuales de Amartya Sen: Aristóteles, Adam Smith y Karl Marx. Madrid: Centro de Estudos Políticos y Constitucionales, 2008. p. 34.

19 "Sen dedicou grande parte de sua carreira justamente à missão de conceber índices sociais e outros mecanismos capazes de ampliar o conteúdo informativo dos procedimentos de decisão coletiva". ARAUJO, Luiz Bernardo Leite; CREDER, Fábio dos Santos. Ética, economia e justiça: a escolha social no pensamento de Sen e Smith. Dois Pontos, Curitiba, v. 10, n. 1, abr. 2013 . p. 117. 20 SANCHEZ GARRIDO, Pablo. Raíces intelectuales de Amartya Sen: Aristóteles, Adam Smith y Karl Marx. Madrid: Centro de Estudos Políticos y Constitucionales, 2008. p. 35.

21 À crítica seniana ao utilitarismo — pautado pela satisfação dos desejos pessoais — antecede a admissão de virtudes dessa abordagem por Sen, quais sejam, a consideração (i) dos resultados, ao se julgar as disposições sociais e (ii) do bem-estar das pessoas ao se julgar os resultados das disposições sociais. 
tras considerações desatreladas da utilidade e porque a visão de bem-estar é suscetível a "condicionamento mental e atitudes adaptativas" 22 .

Também em relação ao liberalismo igualitário de John Rawls, não há uma refutação in totum ${ }^{23}$. Sen converge com certos aspectos da proposta de Rawls, sobretudo a meta máxima humana da autorrealização, mas diverge de pontos centrais de análise dos caminhos de uma justiça igualitária, em especial no que tange à ideia rawlsiana de igualação de bens primários, a supor a possibilidade de uma homogeneidade de interesses e desejos no modo em que cada indivíduo se autorrealiza, proposta que é negada por $\operatorname{Sen}^{24}$.

Diante desse caminho intelectual, fala-se na existência de um "Primeiro Sen", mais voltado à questão econômica e sua abordagem ética, com contribuições para os campos do desenvolvimento econômico planificado, da Teoria da Eleição Social e da conceituação e medição da pobreza e da fome, o que corresponde à sua produção entre os anos 50 e 70 do século XX. A partir dos anos 80, emerge o "Segundo Sen", debruçado sobre a filosofia e enfrentando os motes da liberdade, igualdade e justiça, com atenção para as controvérsias sobre valores universais versus diferenças culturais e para a justificação dos direitos humanos ${ }^{25}$. E o advento marcante da transição do Primeiro ao Segundo Sen é justamente a enunciação da teoria do enfoque das capacidades (capability approach), realizada, pela primeira vez, no artigo Equality of What?, de $1980^{26}$.

Antecedentemente à formulação dessa teoria e a propósito de seus estudos sobre pobreza e fome, Sen já havia cunhado a categoria dos intitulamentos ou habilitações (entitlements), que consiste no conjunto de bens ou recursos de que uma pessoa pode dispor ou que está habilitada de fato e direito a usar ${ }^{27}$. Essa categoria viria a se relacionar com as três outras que estruturam o enfoque das capacidades: os funcionamentos (functionings), as capacidades (capability) e agência (agency).

De inspiração admitidamente aristotélica, a noção de funcionamentos abarca "tudo aquilo que uma pessoa pode considerar valioso fazer ou ter" ${ }^{28}$, sendo possível, por meio deles, obter as informações sobre o que uma pessoa faz, como age, suas qualidades e sua maneira de viver, denotando qual a sua situação e seu modo de vida, aludindo, portanto, a uma conexão entre funcionamento, qualidade de vida e necessidades básicas ${ }^{29}$.

Já a capacidade, no sentido seniano, conforma-se pelas combinações de funcionamentos cuja realização seja factível (de fato viável) para a pessoa ${ }^{30}$. A agência designa a habilidade efetiva da pessoa para realizar os

22 SEN, Amartya. Desenvolvimento como liberdade. São Paulo: Companhia das Letras, 2010. p. 86-89.

23 "[...] tanto a teoria de Sen, quanto a de Rawls, almejam a meta correta, que é a liberdade para realizar, e não a realização propriamente dita, mas percorrem caminhos diferentes". DAOU, Heloisa Sami; BRITO FILHO, José Claudio Monteiro de. John Rawls e Amartya Sen: paralelo entre a teoria de justiça como equidade e a justiça focada nas realizações. Revista de Teorias da Justiça, da Decisão e da Argumentação Jurídica, v. 3, n. 2, p. 01-21, 2017. p. 13-15.

24 "Ao analisar a abordagem de Rawls, Sen afirma que, caso as pessoas fossem basicamente muito semelhantes, então um índice de bens primários poderia ser um bom caminho para julgar as vantagens. Mas, na verdade, as pessoas parecem ter necessidades muito diferentes, variando com a saúde, a longevidade, condições climáticas, localização, temperamento, e até mesmo com o tamanho do corpo - que afeta as necessidades alimentares e de vestuário". SANTOS, Cezar Augusto Pereira dos et al. Bem-estar e pobreza: a abordagem de Sen em comparação à utilitarista e a dos bens primários. Revista Economia \& Tecnologia, v. 9, n. 4, 2013. p. 68.

25 SANCHEZ GARRIDO, Pablo. Raíces intelectuales de Amartya Sen: Aristóteles, Adam Smith y Karl Marx. Madrid: Centro de Estudos Políticos y Constitucionales, 2008. p. 25-26 e 68-69.

26 SEN, Amartya. Equality of What? The Tanner lecture on human values. Stanford, 1980. v. 1. p. 195-220.

27 SANCHEZ GARRIDO, Pablo. Raices intelectuales de Amartya Sen: Aristóteles, Adam Smith y Karl Marx. Madrid: Centro de Estudos Políticos y Constitucionales, 2008. p. 39.

28 Os funcionamentos passíveis de valorização podem ser desde aqueles simples e vinculados à sobrevivência — v.g. estar adequadamente alimentado e protegido de doenças — até aqueles mais complexos — v.g. participar da vida comunitária e ter respeito próprio. SEN, Amartya. Desenvolvimento como liberdade. São Paulo: Companhia das Letras, 2010. p. 104.

29 SANCHEZ GARRIDO, Pablo. Raices intelectuales de Amartya Sen: Aristóteles, Adam Smith y Karl Marx. Madrid: Centro de Estudos Políticos y Constitucionales, 2008. p. 41.

30 "Portanto, a capacidade é um tipo de liberdade: a liberdade substantiva de realizar combinações alternativas de funcionamentos (ou, menos formalmente expresso, a liberdade para ter estilos de vida diversos). Por exemplo, uma pessoa abastada que faz jejum pode ter a mesma realização de funcionamento quanto a comer ou nutrir-se que uma pessoa destituída, forçada a passar fome extrema, mas a primeira pessoa possui um 'conjunto capacitário' diferente do da segunda (a primeira pode escolher comer bem e ser bem nutrida de um modo impossível para a segunda)”. SANCHEZ GARRIDO, Pablo. Raíces intelectuales de Amartya Sen: Aristóteles, 
funcionamentos desejados, sendo seu oposto a imposição a alguém de um agir forçado ou de uma opressão ou, ainda, de uma condição passiva ${ }^{31}$.

Sob o signo dessas categorias interligadas, Sen propõe a ampliação do conceito de pobreza, para que passe a ser compreendida como "privação de capacidades básicas", não se restringindo, então, ao "baixo nível de renda, que é o critério tradicional de identificação da pobreza"32. Para Sen, "a relação instrumental entre baixa renda e baixa capacidade é variável entre comunidades e até mesmo entre famílias e indivíduos (o impacto da renda sobre as capacidades é contingente e condicional)"33.

A Teoria do Enfoque das Capacidades guarda influência direta das reflexões do "jovem Marx" acerca das noções de liberdade, autorrealização e propriedade, as quais redundam na aspiração marxiana de substituição do domínio das circunstâncias sobre os indivíduos pelo domínio desses sobre aquelas. Ideias que inspiram Sen a alçar ao centro de suas propostas econômico-filosóficas a ampliação da capacidade do ser humano de obter bem-estar, entendido este como a liberdade de, autonomamente, desenvolver seus funcionamentos e satisfazer suas necessidades, conforme o que valorize para $\mathrm{si}^{34}$.

Em verdade, encontra-se mais comumente na obra de Sen a referência a "liberdades" (no plural). O pensamento seniano identifica liberdades substantivas e liberdades instrumentais. As liberdades substanciais são aquelas "que temos razão para valorizar", portanto, está atrelado aos interesses livremente eleitos pelo indivíduo. Cada capacidade à feição seniana (capability) é uma liberdade substantiva ${ }^{36}$ e as liberdades substantivas incluem "capacidades elementares", v.g de evitar privações como a fome e a morte prematura, bem como de saber ler, fazer cálculos aritméticos, ter participação política e fruir da liberdade de expressão ${ }^{37}$. Já as liberdades instrumentais favorecem as aquisições e expansão das capacidades e das liberdades substanciais, tendo a "contribuir para a capacidade geral de a pessoa viver mais livremente, mas também têm o efeito de complementar umas às outras" ${ }^{38}$. Em Desenvolvimento como Liberdade, são examinadas 5 liberdades instrumentais: liberdades políticas, facilidades econômicas, oportunidades sociais, garantia de transparência e segurança protetora.

As liberdades políticas são tomadas de modo amplo, de forma a incluir os chamados direitos civis e políticos, e verificam-se com a oportunidade de as pessoas participarem da determinação de quem as governa e com fulcro em quais princípios, podendo exercer, livremente (sem censura direta ou à imprensa),

Adam Smith y Karl Marx. Madrid: Centro de Estudos Políticos y Constitucionales, 2008. p. 105.

31 ALKIRE, Sabina; DENEULIN, Séverine. An introduction to the buman development and capability approach. London: Earthscan, 2009. p. 11. Disponível em: http://citeseerx.ist.psu.edu/viewdoc/download?doi=10.1.1.383.6231\&rep=rep1\&type=pdf. Acesso em: 17 dez. 2019.

32 Sob essa perspectiva, a pobreza designa uma condição de privações de capacidades "intrinsecamente importantes", para além da baixa renda, "que é importante apenas instrumentalmente", havendo de se admitir a existência de outras influências sobre a pobreza real, como, por exemplo, inter alia, idade, "papéis sexuais e sociais" (obrigações familiares determinadas pelo costume), localização (propensão a intempéries, ambiente violento, região populosa, suscetibilidade a doenças, etc.). SEN, Amartya. Desenvolvimento como liberdade. São Paulo: Companhia das Letras, 2010. p. 120.

33 SEN, Amartya. Desenvolvimento como liberdade. São Paulo: Companhia das Letras, 2010. p. 120-121.

34 SANCHEZ GARRIDO, Pablo. Raices intelectuales de Amartya Sen: Aristóteles, Adam Smith y Karl Marx. Madrid: Centro de Estudos Políticos y Constitucionales, 2008. p. 515. Curiosamente, Garrido afirma ter havido uma inversão cronológica na influência marxiana de Sen, de modo que as digressões mais relacionadas à economia política e à crítica do capitalismo do "velho Marx" impactaram mais o "jovem Sen”, enquanto que os pensamentos do "jovem Marx” sobre a liberdade, a autonomia e a autorrealização do ser humano frente à propriedade são grande fonte para o "velho Sen" e seus estudos filosóficos da maturidade. SANCHEZ GARRIDO, Pablo. Raíces intelectuales de Amartya Sen: Aristóteles, Adam Smith y Karl Marx. Madrid: Centro de Estudos Políticos y Constitucionales, 2008. p. 365 e 480. De todo modo, Sen compreende tanto Marx (sobretudo o "jovem") quanto Adam Smith como continuadores do legado aristotélico atinente à "liberdade para realizar-se" como intrinsecamente importante à condição humana. SANCHEZ GARRIDO, Pablo. Raices intelectuales de Amartya Sen: Aristóteles, Adam Smith y Karl Marx. Madrid: Centro de Estudos Políticos y Constitucionales, 2008. p. 157.

35 SEN, Amartya. Desenvolvimento como liberdade. São Paulo: Companhia das Letras, 2010. p. 29.

36 SEN, Amartya. Desenvolvimento como liberdade. São Paulo: Companhia das Letras, 2010. p. 105.

37 SEN, Amartya. Desenvolvimento como liberdade. São Paulo: Companhia das Letras, 2010. p. 55.

38 SEN, Amartya. Desenvolvimento como liberdade. São Paulo: Companhia das Letras, 2010. p. 58. 
a fiscalização e crítica de seus governantes e a escolha entre diferentes partidos políticos). As facilidades econômicas "são as oportunidades que os indivíduos têm para utilizar recursos econômicos com propósitos de consumo, produção ou troca", o que demanda que, aos resultados positivos do crescimento econômico, corresponda o "aumento de intitulamentos econômicos de toda a população", denotando a centralidade das considerações distributivas adicionalmente às agregativas). As oportunidades sociais dizem respeito ao acesso à educação, saúde, alimento e todos os demais bens ou serviços que influenciem, positivamente, a liberdade da pessoa de viver melhor, tanto na dimensão da vida privada — a exemplo da proteção da saúde, contra a morbidez evitável — quanto da participação no espaço público, em atividades econômicas e políticas (para o que é fundamental, entre outras oportunidades, a educação). A garantia de transparência remete à presunção básica de confiança entre as pessoas, nos espaços privado e público, e demanda mecanismos de salvaguarda de "dessegredo e clareza", com isso pretendendo-se evitar "corrupção, irresponsabilidade financeira e transações ilícitas". Por fim, a segurança protetora reclama a proteção social do Estado às pessoas em condição de vulnerabilidade em razão de "mudanças materiais que afetem adversamente suas vidas", levando-as ao limiar da pobreza, da fome e até da morte. Diz respeito, por conseguinte, a disposições institucionais que assegurem benefícios, complemento de renda e outras medidas peculiares (distribuição de alimentos, abrigo etc.) a desempregados, idosos e outros necessitados ${ }^{39}$.

Argumenta, ainda, Sen, que as liberdades tratadas envolvem processos e oportunidades: processos que viabilizam ações e decisões e oportunidades que as pessoas têm de se autorrealizar, a depender de suas circunstâncias individuais e sociais ${ }^{40}$.

É com esse arsenal teórico de categorias que se inter-relacionam que Sen confecciona uma abordagem própria sobre o conceito de desenvolvimento que irá ganhar o mundo e, pelas mãos do PNUD, ser institucionalizado como parâmetro de cooperação internacional sobre o tema.

As noções de liberdades substantivas e instrumentais estruturarão a ideia seniana desenvolvimentista, centrada da enunciação do desenvolvimento como um processo que tem por fim a expansão das liberdades individuais, mas que também tem nas liberdades seu meio de consecução ${ }^{41}$. Em outras palavras, o desenvolvimento é um processo de expansão de liberdades substanciais, para cuja consecução demanda-se, igualmente, a expansão das liberdades instrumentais. Desse modo, as ideias de bem-estar e de posição de vantagem de alguém não são aferidas com base no que essa pessoa de fato realiza, mas das liberdades que frui para realizar ou não o que valoriza. Essa percepção deve informar a análise e estabelecimento de políticas públicas, direitos e oportunidades ${ }^{42}$. Nessa perspectiva, a meta do desenvolvimento deve ser a ampliação das liberdades individuais pela "remoção das principais fontes de privação da liberdade: pobreza e tirania, carência de oportunidades econômicas e destituição social sistemática, negligência dos serviços públicos e intolerância ou interferência excessiva de Estados repressivos" ${ }^{43}$.

Não são poucas as críticas lançadas ao que se tomou por viés individualista do pensamento seniano, supostamente contrário a uma visão social do bem-estar. Acusa-se Sen de pugnar por uma análise do desenvolvimento, com base em uma perspectiva atomizada do sujeito, na medida em que é para o aspecto personalíssimo que remetem as categorias das capacidades, dos funcionamentos e da agência.

A respeito, Robeyns explica haver três tipos de individualismo aplicados ao pensamento social. Há o individualismo ético, que prega a individualidade como unidade última do interesse moral e que as instituições

\footnotetext{
39 SEN, Amartya. Desenvolvimento como liberdade. São Paulo: Companhia das Letras, 2010. p. 25 e 58-60.

40 "A privação de liberdade pode surgir em razão de processos inadequados (como violação do direito ao voto ou de outros direitos políticos ou civis), ou de oportunidades inadequadas que algumas pessoas têm para realizar o mínimo que gostariam (incluindo a ausência de oportunidades elementares como a capacidade de escapar da morte prematura, morbidez voluntária ou fome involuntária)". SEN, Amartya. Desenvolvimento como liberdade. São Paulo: Companhia das Letras, 2010. p. 32.

41 SEN, Amartya. Desenvolvimento como liberdade. São Paulo: Companhia das Letras, 2010. p. 55

42 SEN, Amartya. Sobre ética e economia. São Paulo: Companhia das Letras, 1999. p. 63.

43 SEN, Amartya. Sobre ética e economia. São Paulo: Companhia das Letras, 1999. p. 17.
} 
e estruturas sociais serão sempre avaliadas à luz de sua importância para o bem-estar individual. Já o individualismo ontológico, mais radical, preceitua que a sociedade é, e sempre será, constituída por indivíduos e conformada pela soma desses indivíduos e suas características. Já o individualismo metodológico presume que todo fenômeno social pode ser explicado a partir dos indivíduos e de suas características ${ }^{44}$.

Para a autora, o enfoque das capacidades contempla o individualismo ético, mas é crucial admitir que tal postura não é incompatível com uma abordagem ontológica que considere as relações entre pessoas, suas relações sociais e a incorporação social, assim como que políticas sociais destinadas a certos grupos ou comunidades são perfeitamente compatíveis com o individualismo ético ${ }^{45}$. Garrido, por sua vez, recorda que, em distintas oportunidades, Sen respondeu a seus críticos destacando que mais do que não conceber a análise social do indivíduo separada do seu ambiente social, defende justamente essa associação, buscando apoio em Marx como um exemplo de uma visão metodológica individualista, mas também holística ${ }^{46}$.

O caráter social das propostas de Sen sobre o desenvolvimento como expansão das liberdades manifesta-se, no campo teórico, por seus aportes à Teoria da Escolha Social e, no campo empírico, por sua contribuição à construção e aperfeiçoamento do IDH, divulgado pelo PNUD, aspirando, como dito, consubstanciar-se em fonte informativa de políticas públicas globais, nacionais e locais.

Assim enuncia o pensador indiano o problema fundamental da Teoria da Escolha Social: é possível e, se sim, como obter deliberações racionais, razoáveis e cogentes sobre as preferências da sociedade, diante da diversidade de desejos, preocupações e condições dos diferentes indivíduos que integram a sociedade ${ }^{47}$ Em suma, trata-se de enfrentar o problema das decisões de amplitude social, o que, embora já refletido por Aristóteles, configurou-se em uma teoria sistematizada apenas ao tempo da Revolução Francesa, pelos matemáticos franceses J. C. Borda e Marquês de Condorcet, motivados a encontrar um modo de evitar a insegurança e a arbitrariedade nas decisões sociais ${ }^{48}$.

Tal teoria viria a ser revivida por trabalhos de meados do século XX pelo economista e matemático estadunidense Kenneth Arrow, autor do "Teorema da Impossibilidade", segundo o qual é impossível elegerem-se, de modo consistente, preferências que conduzam a escolha social, exceto em uma situação de ditadura, o que, todavia, cobraria ao alto preço do sacrifício da participação democrática nas decisões sociais e da insensibilidade governamental quanto à condução da economia de bem-estar capaz de abarcar todos os interesses heterogêneos sob administração ${ }^{49}$.

Criticando o que entende ser o estabelecido uso inadequado de técnicas matemáticas pela Teoria da Escolha Social, Sen entende que essa análise é mais complexa e exige a abordagem de outros aspectos, mas, em especial, o reconhecimento de que, ante a diversidade de individualidades, deve haver um processo democrático e inclusivo de deliberação sobre as preferências a serem socialmente contempladas, cujo resultado não está plenamente sujeito a antecipações por racionalidades formais, como a matemática, já que pode haver insights e conformações inesperadas — o que não reduz a importância das investigações formais sobre as combinações de valores e consensos obtidos ${ }^{50}$.

\footnotetext{
44 ROBEYNS, Ingrid. An unworkable idea or a promising alternative? Sen's capability approach re-examined. Discussion Paper Series, Katholieke Universiteit Leuven. Faculty of Economics and Applied Economics, p. 1-33, 2000. p. 16-17.

45 ROBEYNS, Ingrid. An unworkable idea or a promising alternative? Sen's capability approach re-examined. Discussion Paper Series, Katholieke Universiteit Leuven. Faculty of Economics and Applied Economics, p. 1-33, 2000. p. 16-17.

46 SANCHEZ GARRIDO, Pablo. Raíces intelectuales de Amartya Sen: Aristóteles, Adam Smith y Karl Marx. Madrid: Centro de Estudos Políticos y Constitucionales, 2008. p. 534. De fato, no Prefácio de Desenvolvimento como Liberdade consta: "Existe uma acentuada complementaridade entre a condição de agente individual e as disposições sociais: é importante o reconhecimento simultâneo da centralidade da liberdade individual e da força das influências sociais sobre o grau e o alcance da liberdade individual. Para combater os problemas que enfrentamos, temos de considerar a liberdade individual um compromisso social”. SEN, Amartya. Desenvolvimento como liberdade. São Paulo: Companhia das Letras, 2010. p. 10.

47 SEN, Amartya. The Possibility of Social Choice. The American Economic Review, v. 89, n. 3, p. 349-378, 1999. p. 349.

48 SEN, Amartya. The Possibility of Social Choice. The American Economic Review, v. 89, n. 3, p. 349-378, 1999. p. 350.

49 SEN, Amartya. The Possibility of Social Choice. The American Economic Review, v. 89, n. 3, p. 349-378, 1999. p. 351.

50 SEN, Amartya. The Possibility of Social Choice. The American Economic Review, v. 89, n. 3, p. 349-378, 1999. p. 353.
} 
É possível perceber que a pluralidade subjetiva que motiva o problema da Teoria da Escolha Social é a mesma que impede Sen de adotar, a priori, um rol acabado de liberdades e capacidades prioritárias a serem privilegiadas no processo de desenvolvimento, conquanto, em seus estudos, usualmente mencione algumas também referidas nos estudos de sua principal inspiração aristotélica contemporânea, Martha Nussbaum ${ }^{51}$. Não obstante, aponta-se a necessidade de que a Teoria da Escolha Social contemple, da mesma maneira e com a mesma preocupação, os aspectos de oportunidade e processual das liberdades, superando uma tendência de privilégio do primeiro sobre o segundo ${ }^{52}$.

Por outro lado, Sen chama a atenção para o fato de deliberações baseadas em votações decididas por maioria (eleições, referendos ou soluções por comitês) serem adequadas para algumas questões, mas não para outras, como é o caso das políticas econômicas de bem-estar social, porquanto não se pode admitir sejam ignorados os interesses atinentes à qualidade de vida — i.e. às liberdades e capacidades — daqueles que perderam a votação ou que sequer exerceram a liberdade política de votar. Assim, é preciso ir além do sistema de votação para a escolha de questões distributivas ${ }^{53}$.

A propósito, a democracia, no pensamento seniano, é liberdade substantiva em si, mas com função instrumental de aumentar a possibilidade de reivindicações de atenção política (inclusive de cunho econômico) serem atendidas e com o papel construtivo na conceituação das "necessidades econômicas" em sentido social $^{54}$.

O pensamento seniano, como se vê, segue uma tradição indiana de ecletismo ${ }^{55}$ e caracteriza-se por um resultado sincrético suis generis de referências (Aristóteles, Smith e Marx), dificultando, inclusive, seu enquadramento dentro das vertentes da filosofia política ${ }^{56}$.

\section{Mercado, Estado e direitos humanos no pensamento seniano}

Como antecipado, Sen comunga e difunde a percepção smithiana a respeito da conveniência da liberalização do mercado, sem que isso signifique ausência de limites ou não vinculação à distribuição de renda que expanda as liberdades, postura alinhada com todo o seu esforço de retomada da associação entre ética e economia. De fato, o pensamento seniano nega que o mercado por si mesmo seja capaz de expandir capacidades, porque não considera a situação inicial dos intitulamentos, tampouco as vicissitudes dos mais depauperados ${ }^{57}$.

Nessa linha, Sen afirma que o mercado é parte indissociável do processo de desenvolvimento pela sua

51 SANCHEZ GARRIDO, Pablo. Raices intelectuales de Amartya Sen: Aristóteles, Adam Smith y Karl Marx. Madrid: Centro de Estudos Políticos y Constitucionales, 2008. p. 180-186. Nussbaum formula sua própria teoria das capacidades, apresentando uma lista de "capacidades centrais" relacionadas a 5 temas: vida; saúde física; integridade física (engloba liberdade de ir e vir, sexual e de estar seguro contra a violência); sentidos, imaginação e pensamentos; e emoções. NUSSBAUM, Martha C. Creating capabilities. Cambridge: London: Harvard University Press, 2011. p. 33. Sobre o tema: ZEIFERT, Anna Paula Bagetti; STURZA, Janaína Machado Sturza. As políticas públicas e a promoção da dignidade: uma abordagem norteada pelas capacidades (capabilities approch) propostas por Martha Nussbaum. Revista Brasileira de Políticas Públicas, Brasília, v. 9, n. 1, p. 114-126, abr. 2019. Disponível em: https://www.publicacoesacademicas.uniceub.br/RBPP/article/view/5894. Acesso em: 08 mar. 2020.

52 SEN, Amartya. The Possibility of Social Choice. The American Economic Review, v. 89, n. 3, p. 349-378, 1999. p. 364.

53 SEN, Amartya. The Possibility of Social Choice. The American Economic Review, v. 89, n. 3, p. 349-378, 1999. p. 356.

54 SEN, Amartya. Desenvolvimento como liberdade. São Paulo: Companhia das Letras, 2010. p. 195.

55 SANCHEZ GARRIDO, Pablo. Raices intelectuales de Amartya Sen: Aristóteles, Adam Smith y Karl Marx. Madrid: Centro de Estudos Políticos y Constitucionales, 2008. p. 374.

56 Há quem tenha afirmado que Sen promove um "liberalismo social intercultural" ou um "certo socialismo liberal-social multicultural”. SANCHO, Jesus Conill apud SANCHEZ GARRIDO, Pablo. Raíces intelectuales de Amartya Sen: Aristóteles, Adam Smith y Karl Marx. Madrid: Centro de Estudos Políticos y Constitucionales, 2008. p. 75.

57 SANCHEZ GARRIDO, Pablo. Raices intelectuales de Amartya Sen: Aristóteles, Adam Smith y Karl Marx. Madrid: Centro de Estudos Políticos y Constitucionales, 2008. 522. 
capacidade de dinamizar o crescimento econômico. Ademais, como já arguiu Smith, a liberdade de troca e transação é, em si, uma liberdade substantiva que as pessoas têm a possibilidade e razão para valorizar. Aliás, a despeito da relevância do crescimento econômico para o processo de desenvolvimento, a liberdade de troca (de palavras, bens e presentes) o precede em importância ${ }^{58}$. Apreende-se, pois, que a liberdade do mercado, defendida por Sen, pressupõe a liberdade ampla dos indivíduos (todos) de estarem no mercado e poderem realizar as trocas. Trata-se da liberdade econômica. A pobreza extrema, pois, representa a completa privação da liberdade econômica e deixa a pessoa mais suscetível à violação de outras liberdades ${ }^{59}$.

O crescimento econômico e a liberdade econômica, apenas, se justificam como instrumentos de desenvolvimento se observada a necessária distribuição, pois "o principal é que o impacto do crescimento econômico depende muito do modo como seus frutos são aproveitados" "'. Atada a essa reflexão, em Desenvolvimento como Liberdade, há um esforço analítico estatístico para demostrar a inadequação de uma suposta vinculação irredarguível entre privação de renda e privação de capacidades ${ }^{61}$, com a proposta de que, conquanto seja uma relação importante a mantida entre renda e capacidades, a privação de capacidades, por sua maior amplitude, afigura-se mais pertinente para a definição de políticas orientadas ao desenvolvimento ${ }^{62}$. Para tanto, o Estado é chamado a conduzir o processo desenvolvimentista, nesses termos.

Sustenta Sen, citando o contexto do estado indiano de Kerala, que países pobres não necessitam aguardar os frutos do crescimento econômico para obter avanços no processo de incremento da qualidade de vida das pessoas, uma vez que para tanto pode haver custeio público (adequadamente gerido) direcionado para oportunidades de educação básica e saúde ${ }^{63}$. Claramente atacando as propostas neoliberais, Sen rechaça uma "visão compartimentada do processo de desenvolvimento", com soluções que classifica como "únicas e multiuso" - tais como abertura de mercados e ajuste de preços. Aduz que deve haver uma abordagem integrada entre redução da atividade burocrática do Estado, sem, contudo, abrir mão de seu papel crucial de expansão das liberdades instrumentais, mormente das oportunidades sociais e da segurança protetora, até porque há liberdades instrumentais cujos elementos não se encontram no mercado para a aquisição individual, sendo providos coletivamente pelo Estado na forma de "bens públicos", como a preservação ambiental, as gestões epidemiológicas e os serviços públicos de saúde ${ }^{64}$.

Nessa trilha, a análise seniana refuta o apego irrestrito às rigorosas políticas de austeridade fiscal, pois o controle de gastos públicos jamais pode perder de vista os "objetivos globais da política pública” voltadas à geração e garantia de capacidades básicas aos indivíduos, de modo que a necessidade instrumental de estabilidade macroeconômica deve "ser avaliada dentro de uma estrutura de objetivos sociais" ". Até porque a ampliação das oportunidades sociais, com base em medidas de acesso à saúde e à educação pública e de reforma agrária, pode favorecer o crescimento econômico, como revelam os casos das economias japonesa e chinesa, no século $\mathrm{XX}^{66}$.

O Estado, portanto, na visão seniana (e, a seu juízo, desde Smith), tem o papel central de promover as liberdades, inclusive a despeito do mercado, mas também orientando a redistribuição igualitária de seus rendimentos — denotando que as reflexões de Sen partem do exame da situação individual, mas, como assente

58 SEN, Amartya. Desenvolvimento como liberdade. São Paulo: Companhia das Letras, 2010. p. 20.

59 SEN, Amartya. Desenvolvimento como liberdade. São Paulo: Companhia das Letras, 2010. p. 23.

60 SEN, Amartya. Desenvolvimento como liberdade. São Paulo: Companhia das Letras, 2010. p. 66.

${ }^{61}$ Há dados sobre países com incremento de PIB e renda per capita não revertido em solução para a problemas de desigualdade, desemprego e má assistência à saúde, ao passo em que há exemplos de limitada receita pública, mas com resultados positivos na redução de mortalidade infantil e provimento de educação e saúde. SEN, Amartya. Desenvolvimento como liberdade. São Paulo: Companhia das Letras, 2010. p. 36-39, 62-77 e 131-145.

62 SEN, Amartya. Desenvolvimento como liberdade. São Paulo: Companhia das Letras, 2010. p. 35.

63 SEN, Amartya. Desenvolvimento como liberdade. São Paulo: Companhia das Letras, 2010. p. 71.

64 SEN, Amartya. Desenvolvimento como liberdade. São Paulo: Companhia das Letras, 2010. p. 169-171.

65 SEN, Amartya. Desenvolvimento como liberdade. São Paulo: Companhia das Letras, 2010. p. 187.

66 SEN, Amartya. Desenvolvimento como liberdade. São Paulo: Companhia das Letras, 2010. p. 61 e 330. 
Garrido, desde uma perspectiva estatal de interdependência social ${ }^{67}$.

Como dito, é no "Segundo Sen" que se verifica uma atenção mais detida do pensador aos direitos humanos. Em escrito do século XXI, dedicado ao tema, Sen associa os direitos humanos ao enfoque das capacidades, entendendo que aqueles contemplam, a miúde, certas liberdades específicas, intentando assegurar, juridicamente, os intitulamentos (entitlements) de pessoas para determinadas capacidades ${ }^{68}$. Chama a atenção, ainda, para a tendência de os debates sobre direitos humanos debruçarem mais sobre as liberdades em seu aspecto das oportunidades, quando a análise deveria ter a mesma preocupação com seu aspecto processual ${ }^{69}$.

Alude Sen a três argumentos em favor da associação entre liberdades básicas e direitos humanos: "importância intrínseca", "papel consequencial de fornecer incentivos políticos para a segurança econômica" e "papel construtivo na gênese de valores e prioridades" ${ }^{70}$. Todavia, o pensador indiano não descura da questão da multiculturalidade no processo de estabelecimento dos direitos humanos, tema que guarda estrita relação com o enfoque das capacidades e seu destaque para a pluralidade de subjetividades, o que, por consequência, se aplica a povos e culturas. Sen trata esse mote valendo-se de sua já conhecida postura de não aderir a portfólios pré-estabelecidos de liberdades e capacidades básicas, aplicando a mesma ideia aos direitos humanos. Nessa perspectiva, a ênfase volta a recair sobre a observância de um processo democrático e plural de estabelecimento de padrões coletivos e de sua fiscalização, o que também se aplica às ações estatais em prol da expansão das liberdades, em ordem a evitar privações decorrentes da omissão estatal ${ }^{11}$. É o que Sen trata como "processo de razão pública"72.

A respeito de um processo de razão pública internacional, Sen, em escrito dedicado ao tema, admite que sua realização seja feita por organizações e atores internacionais mobilizados por isso e que possibilitem que cada uma das "múltiplas identidades" de interesses, reivindicações e culturas possam tomar assento e ter voz em um espaço de busca de consensos globais, sem sacrifício imposto a particularismos nacionais, em um movimento agregativo que o filósofo denomina "afiliação plural"’3.

Não obstante a confirmação da pertinência dos direitos humanos, Sen afirma ser melhor concebê-los como pretensões éticas não identificadas como "direitos legais legislados", algo que, também a seu juízo, não macula a utilidade da noção de direitos humanos "no tipo de contexto no qual eles são comumente invocados", pois, argumenta: "temos que julgar a plausibilidade dos direitos humanos como um sistema de raciocínio ético e com base em reivindicações políticas" ", para o que, pensa-se, vislumbra Sen a utilidade dos direitos humanos como objeto da cogência normativa.

\footnotetext{
67 SANCHEZ GARRIDO, Pablo. Raíces intelectuales de Amartya Sen: Aristóteles, Adam Smith y Karl Marx. Madrid: Centro de Estudos Políticos y Constitucionales, 2008. p. 535. Segundo Bentes e Brígida, na teoria das capacidades de Sen, a atuação do Estado se mostra pressuposto para concretização das dimensões da liberdade capazes de promover o desenvolvimento econômico e social em termos plurais. BENTES, Natalia Mascarenhas Simões; BRÍGIDA, Yasmin Salgado Santa. Vinculação dos direitos econômicos, sociais e culturais: uma discussão do desenvolvimento humano com base no conceito de Amartya Sen sobre o mínimo existencial. Revista de Direito Internacional, Brasília, v. 15, n. 3, p. 99-121, 2018.

68 SEN, Amartya. Human Rights and Capabilities. Journal of Human Development, v. 6, n. 2, p. 151-166, jul. 2005. p. 152.

69 SEN, Amartya. Human Rights and Capabilities. Journal of Human Development, v. 6, n. 2, p. 151-166, jul. 2005. p. 157.

70 SEN, Amartya. Desenvolvimento como liberdade. São Paulo: Companhia das Letras, 2010. p. 116.

71 Conforme Sen, a omissão estatal verifica-se em governos que não se submetem a controle democrático, exercido por uma imprensa livre, uma oposição ativa. SANCHEZ GARRIDO, Pablo. Raices intelectuales de Amartya Sen: Aristóteles, Adam Smith y Karl Marx. Madrid: Centro de Estudos Políticos y Constitucionales, 2008. p. 523.

72 SEN, Amartya. Human Rights and Capabilities. Journal of Human Development, v. 6, n. 2, p. 151-166, jul. 2005. p. 163.

73 SEN, Amartya. Global justice: beyond international equity. In: KAUL, Inge et al. (eds.) Global public goods: international cooperation in the 21st Century. New York: Oxford: Oxford University Press, 1999. p. 116-125.

74 SEN, Amartya. Desenvolvimento como liberdade. São Paulo: Companhia das Letras, 2010. p. 295.
} 


\section{A teoria aplicada à prática: os Relatórios Desenvolvimento Humano e o IDH}

A divulgação pelo PNUD, desde 1990, do Índice de Desenvolvimento Humano (IDH), de maneira periódica, dentro dos Relatórios de Desenvolvimento Humano (RDHs) globais temáticos, resulta de colaboração direta de Sen com seu amigo e economista paquistanês Mahbub ul Haq. A noção de Desenvolvimento Humano, todavia, deve ser compreendida no contexto das transformações históricas que impactaram a própria concepção de desenvolvimento.

Originariamente, a ideia de desenvolvimento foi conformada por objetivos evolucionistas dos Estados europeus no pós-Guerra, inspirados nos marcos das Revoluções Industrial e Francesa, sendo aquela a referência inicial da industrialização e esta o aspecto valorativo do fenômeno histórico, ambas pautadas nos valores essenciais antropocêntricos da Modernidade: hiper-valorização da liberdade, prevalência da razão e domínio utilitarista sobre a natureza ${ }^{75}$. Essa visão eurocêntrica de desenvolvimento é eminentemente economicista, na medida em que compreende o crescimento econômico com condição suficiente para o desenvolvimento ${ }^{76}$. Outro importante conceito trazido nessa perspectiva é o de industrialismo, pois o processo de desenvolvimento no pós-Guerra pelos Estados denominados "desenvolvidos" se deu por meio da industrialização $\mathrm{O}^{77}$.

A disputa pelo conceito de desenvolvimento foi intensificada durante a Guerra Fria, período que a celeuma sobre inclusão dos direitos econômicos, sociais e culturais no rol de direitos humanos refletia o momento político-social tensionado pela também emergência das desigualdades entre as nações.

Segundo Carniello e Santos, transversalmente à persistência da desigualdade social e econômica, emergiu o debate sobre a preservação dos recursos naturais indispensáveis à sobrevivência da sociedade e à perpetuação do modelo econômico em vigor ${ }^{78}$. Nasce a ideia de desenvolvimento sustentável, suplantadora da perspectiva tradicional economicista, passando-se a uma noção de desenvolvimento econômico, social, cultural, naturalmente político, depois sustentável e humano ${ }^{79}$.

Nesse cenário, o advento do IDH e de sua veiculação pelos RDHs representa a manifestação prática

\footnotetext{
75 AMARO, Rogério Roque. Desenvolvimento ou Pós-Desenvolvimento? Des-Envolvimento e... Noflay! Cadernos de Estudos Africanos, Lisboa, n. 34, jul./dez. 2017. p. 85.

76 AMARO, Rogério Roque. Desenvolvimento: um conceito ultrapassado ou em renovação? Da teoria à prática e da prática à teoria. Cadernos de Estudos Africanos, Lisboa, n. 4, jan./jul. 2003. p. 46. Disponível em: https://revistas.rcaap.pt/cea/article/view/8659. Acesso em: 12 nov. 2019.

77 AMARO, Rogério Roque. Desenvolvimento: um conceito ultrapassado ou em renovação? Da teoria à prática e da prática à teoria. Cadernos de Estudos Africanos, Lisboa, n. 4, jan./jul. 2003. p. 46. Nesse sentido, a "fórmula" do desenvolvimento era composta pela meta do crescimento econômico a partir da industrialização. Tal ponto de vista foi diretamente criticado por Trubek, sob o argumento de que a realidade dos países subdesenvolvidos não era necessariamente essa, a exigir que se admitam outros caminhos para o desenvolvimento, que não apenas pela proteção jurídica e promoção da propriedade e do investimento industrial. TRUBEK, David. Para uma teoria social do direito: um ensaio sobre o estudo do direito e desenvolvimento. In: RODRIGUEZ, José Rodrigo (org.). O novo direito e desenvolvimento: presente, passado e futuro. São Paulo: Saraiva, 2009. p. 51-122. p. 60-65.

${ }_{78}$ SANTOS, Moacir José dos; CARNIELLO, Monica Franchi. História do desenvolvimento: limites de um campo de pesquisa. Revista Brasileira de Gestão e Desenvolvimento Regional, Taubaté, v. 10, n. 3, 2014. p. 70.

79 SACHS, Ignacy. O desenvolvimento enquanto apropriação dos direitos humanos. Estudos Avançados, São Paulo, v. 12 , n. 33 , 1998. p. 150. Disponível em: http://www.scielo.br/pdf/ea/v12n33/v12n33a11.pdf. Acesso em: 19 nov. 2019. A perspectiva sustentável se consolidou no âmbito das Nações Unidas, em 1987, no relatório "Nosso Futuro Comum”, assinado por Gro Harlem Brundtland, então primeira-ministra norueguesa e chefe da Comissão Mundial sobre o Meio Ambiente e Desenvolvimento, instituída pela ONU. O documento ficou conhecimento como Relatório Brundtland. NASCIMENTO, Elimar Pinheiro do. Trajetória da sustentabilidade: do ambiental ao social, do social ao econômico. Estudos Avançados, São Paulo, v. 26, n. 74, 2012. p. 54. Disponível em: http:// www.scielo.br/scielo.php?pid=S0103-40142012000100005\&script=sci_abstract\&tlng=pt. Acesso em: 10 dez. 2019. Corrobora o fenômeno o fato dos RDHs de 2001, 2006 e 2011 haverem ressaltado o aumento na degradação da natureza, principalmente com a dilapidação dos recursos naturais, sobrecarga dos recursos e poluentes, bem como perda da biodiversidade. PNUD. Relatório do Desenvolvimento Humano 2001: fazendo as novas tecnologias trabalhar para o desenvolvimento humano. Nova Iorque: PNUD, 2001. p. 113-114; PNUD. Relatório do Desenvolvimento Humano 2006: a água para lá da escassez: poder, pobreza e a crise mundial da água. Nova Iorque: PNUD, 2006. p. 27-28. PNUD. Relatório do Desenvolvimento Humano 2011: sustentabilidade e equidade: um futuro melhor para todos. Nova Iorque: PNUD, 2011. p. IV, 2-4.
} 
do pensamento seniano naquilo em que preceitua que a Escolha Social e, por conseguinte a formulação da intervenção estatal pela via das políticas públicas, deve ser exercitada a partir de uma base informacional adequada, tarefa não cumprida a contento pelas apurações matemáticas e formais típicas dos desenvolvimentistas ortodoxos do século XX. Nas palavras do próprio Sen, o IDH conjuga uma lista mínima de capacidades, reunidas com o único objetivo de oferecer a possibilidade de se apurar, coletivamente, a situação da qualidade básica de vida, com apoio em estatísticas alternativas ao uso exclusivo do PIB e à renda per capita ${ }^{80}$.

Desde essa miríade de categorias e expressões que compõem a teoria e as ações internacionais para o desenvolvimento, convém perceber que a expressão Desenvolvimento Humano remete, especificamente, a uma ideia avaliativa do processo de expansão de liberdades (e, para tanto, de capacidades), cuja medição pelo IDH pretende oferecer um panorama estatístico informador do processo de Escolha Social e de formatação de políticas públicas voltadas ao Desenvolvimento Sustentável (em todas as suas múltiplas dimensões e não apenas na dimensão da renda), para tanto permitindo, de um lado, a constatação da existência de privações de liberdades substanciais e instrumentais (nos âmbitos global, nacional e local) e, de outro, a apuração e análise dos resultados das medidas adotadas sob o propósito desenvolvimentista.

A transição de conteúdo da noção de desenvolvimento econômico ao desenvolvimento sustentável também impactou a regulação sobre o tema, erigida na seara da governança global, notadamente no marco da ONU, como se afere da sucessão de declarações atinentes ao tema - Declaração sobre o Direito ao Desenvolvimento (1986), Declaração do Rio sobre Meio Ambiente e Desenvolvimento (1992), Declaração e Programa de Ação da Cúpula Mundial sobre Desenvolvimento de 1995 - e dos compromissos internacionais celebrados em torno dos Objetivos do Milênio (2000), posteriormente sucedidos pelos Objetivos do Desenvolvimento Sustentável ou "Agenda 2030" (2015), consolidando a concepção multidimensional do desenvolvimento, a abranger aspectos econômico, social, sustentável e humano.

As relações de trabalho são contempladas pela multidimensionalidade conceitual da ideia de Desenvolvimento Sustentável, atraindo, por conseguinte, atenção no que se refere às medidas orientadas à sua promoção e à sua mediação. Consequentemente, não há falar-se em Desenvolvimento Sustentável e em Desenvolvimento Humano, sem abordar-se o tema do trabalho. Por tais motivos, também a regulação internacional da tensão capital-trabalho não ficou alheia à influência desenvolvimentista, em seus contornos contemporâneos, do que é expressão maior justamente a concepção de Trabalho Decente e seus desdobramentos práticos.

\section{Trabalho Decente: motor do Desenvolvimento Humano}

O título desse tópico replica a afirmação que também intitula o RDH de 2015. Foram necessários 25 anos desde o primeiro relatório publicado pelo PNUD para que um RDH tivesse por tema principal o Trabalho Decente.

O trabalho sempre foi abordado por todos os RDHs, ora com mais ênfase, ora menos, sempre tangencialmente aos temas que protagonizaram os estudos. Invariavelmente, as relações de trabalho foram versadas em sua função de instrumento de acesso à renda e combate à pobreza (privações), a despeito de o RDH de 2000, intitulado "Direitos Humanos e Desenvolvimento Humano - pela Liberdade e Solidariedade"

\footnotetext{
80 SEN, Amartya. Human Rights and Capabilities. Journal of Human Development, v. 6, n. 2, p. 151-166, jul. 2005. p. 159. Atualmente, o IDH é composto, em sua forma básica, pela associação dos seguintes indicadores: expectativa de vida ao nascimento, expectativa de anos de escolarização, média efetiva de anos de escolarização e PIB per capita, denotando alusão a algumas das liberdades substantivas mais examinadas por Sen em seus estudos teóricos e ilustrações empíricas. Acerca da uma suposta contradição entre o IDH e sua recusa em pré-estabelecer listas de capacidades básicas, Sen defende-se que se trata de uma lista mínima e não exaustiva, com finalidade específica e que não desvalida outras listas que possam ser confeccionadas. SEN, Amartya. Human Rights and Capabilities. Journal of Human Development, v. 6, n. 2, p. 151-166, jul. 2005. p. 159.
} 
haver incluído a liberdade para o Trabalho Decente, sem exploração, no rol do que enunciou como sendo as 7 liberdades básicas ${ }^{81}$. É, de fato, uma constante na série histórica dos RDHs a reivindicação, de um lado, de medidas de inserção no mercado de trabalho para pessoas em condição de vulnerabilidade de qualquer natureza (inclusive as vitimadas pelo próprio desemprego), e, de outro, de prestação de assistência social pelo Estado a esse mesmo grupo de indivíduos ${ }^{82}$.

Antes do RDH temático de 2015 sobre Trabalho Decente, merecem menções mais detidas as análises dos RDHs de 2010 e 2013 sobre as relações laborais.

Em exame retrospectivo de dados e análises de todos os relatórios publicados desde 1990, o RDH de 2010, intitulado “A Verdadeira Riqueza das Nações: Vias para o Desenvolvimento Humano" — em alusão explícita da inspiração smithiana da Teoria de Sen —, afirma estar demonstrado que os três componentes elementares do IDH (rendimento, longevidade e educação) não guardam relação de implicação, pois se evidenciou a existência de países pobres ou em desenvolvimento que incrementaram seus níveis de saúde e educação, a despeito de não crescerem economicamente, enquanto outros Estados economicamente favorecidos não lograram expansão do acesso à saúde e educação de sua população ${ }^{83}$.

Repisando a crítica ao desenvolvimentismo economicista, o RDH de 2010 desmente a relação supostamente necessária entre crescimento econômico e oportunidades de Trabalho Decente, embora admita ocorrências em que tal relação seja aferível ${ }^{84}$.

\footnotetext{
81 O RDH de 2000 afirma a associação entre Direitos Humanos e Desenvolvimento Humano, a partir do asseguramento das nominadas The Seven Freedoms: liberdade em face a discriminação (de gênero, raça, etnia, nacionalidade e religião), liberdade em face do medo de afronta à segurança pessoal, da tortura, da prisão arbitrária e de outros atos violentos; liberdade de pensamento, de expressão, de reunião e de deliberação; liberdade para desejar e usufruir de um padrão decente de vida; liberdade para desenvolver e realizar o potencial humano individual; liberdade em face da injustiça e da violação do devido processo legal; e liberdade para o Trabalho Decente, sem exploração. UNDP. Human Development Report 2000: Human Rights and Human Development. New York: UNDP, 2000. p. 01. Disponível em: https://www.br.undp.org/content/brazil/pt/home/library/idh/relatorios-de-desenvolvimento-humano/relatorio-do-desenvolvimento-humano-2000.html. Acesso em: 18 dez. 2019.

82 Cf., exemplificativamente: PNUD. Relatório do Desenvolvimento Humano 2001: fazendo as novas tecnologias trabalhar para o desenvolvimento humano. Nova Iorque: PNUD, 2001. Disponível em: https://www.br.undp.org/content/brazil/pt/home/library/ $\mathrm{idh} /$ relatorios-de-desenvolvimento-humano/relatorio-do-desenvolvimento-humano-20001.html. Acesso em: 18 dez. 2019 . PNUD. Relatório do Desenvolvimento Humano 2004: liberdade cultural num mundo diversificado. Nova Iorque: PNUD, 2004. Disponível em: https://www.br.undp.org/content/brazil/pt/home/library/idh/relatorios-de-desenvolvimento-humano/relatorio-do-desenvolvimento-humano-20004.html. Acesso em: 18 dez. 2019. PNUD. Relatório do Desenvolvimento Humano 2005: cooperação internacional numa encruzilhada. Nova Iorque: PNUD, 2005. Disponível em: https://www.br.undp.org/content/brazil/pt/home/library/idh/ relatorios-de-desenvolvimento-humano/relatorio-do-desenvolvimento-humano-20005.html. Acesso em: 18 dez. 2019. PNUD. Relatório do Desenvolvimento Humano 2009. Disponível em: https://www.br.undp.org/content/brazil/pt/home/library/idh/relatorios-de-desenvolvimento-humano/relatorio-do-desenvolvimento-humano-20009.html. Acesso em: 18 dez. 2019. PNUD. Ultrapassar barreiras: mobilidade e desenvolvimento humanos. Nova Iorque: PNUD, 2009. PNUD. Relatório do Desenvolvimento Humano 2011. Disponível em: https://www.br.undp.org/content/brazil/pt/home/library/idh/relatorios-de-desenvolvimento-humano/ relatorio-do-desenvolvimento-humano-200011.html. Acesso em: 18 dez. 2019. PNUD. Sustentabilidade e equidade: um futuro melhor para todos. Nova Iorque: PNUD, 2012. PNUD. Relatório do Desenvolvimento Humano 2014: sustentar o progresso humano: reduzir as vulnerabilidades e reforçar a resilência. Nova Iorque: PNUD, 2014. Disponível em: https://www.br.undp.org/content/brazil/pt/ home/library/idh/relatorios-de-desenvolvimento-humano/relatorio-do-desenvolvimento-humano-200013.html. Acesso em: 18 dez. 2019.

83 PNUD. Relatório do Desenvolvimento Humano 2010: a verdadeira riqueza das nações: vias para o desenvolvimento humano. Nova Iorque: PNUD, 2010. p. 48-56. Disponível em: https://www.br.undp.org/content/brazil/pt/home/library/idh/relatorios-de-desenvolvimento-humano/relatorio-do-desenvolvimento-humano-200010.html. Acesso em: 18 dez. 2019.

84 O RDH de 2010, ainda, destaca a função primordial do Estado na mediação da relação entre empresas, trabalhadores, comunidades e o próprio Estado, em especial pela via da regulação e de sua salvaguarda pelas instituições, com vistas à limitação do abuso do mercado e à redistribuição de renda, haja vista a experiência demonstrar que a plena liberdade do mercado acarreta barateamento da mão-de-obra associada à explosão do exército de reserva (desemprego estrutural) e ao desprezo pela saúde dos trabalhadores. PNUD. Relatório do Desenvolvimento Humano 2010: a verdadeira riqueza das nações: vias para o desenvolvimento humano. Nova Iorque: PNUD, 2010. p. 65-66. Nessa senda, esse RDH confronta o corrente discurso neoliberal sobre o custo dos direitos trabalhistas como desvantagem comercial e obstáculo ao desenvolvimento econômico, bem como clama pela proteção do emprego. PNUD. Relatório do Desenvolvimento Humano 2010: a verdadeira riqueza das nações: vias para o desenvolvimento humano. Nova Iorque: PNUD, 2010. p. 51, 65-66, 78-85. Disponível em: https://www.br.undp.org/content/brazil/pt/home/library/idh/ relatorios-de-desenvolvimento-humano/relatorio-do-desenvolvimento-humano-200010.html. Acesso em: 18 dez. 2019.
} 
Ao tempo em que revisita critérios e metodologias de análises e percepções de seus antecessores, o RDH de 2010 inova em relação àqueles, trazendo indicadores relativos à vulnerabilidade, dentre os quais há um indicador intitulado "Trabalho Decente", composto (com desagregação por gênero) por: taxa de população empregada, taxa de empregos formais, taxa de emprego vulnerável (trabalho familiar não pago ou por conta própria), taxa de pessoas empregadas que vivem com menos de US $\$ 1,25$ por dia, taxa de desemprego por nível de educação, taxa de trabalho infantil e número de dias úteis de gozo de licença maternidade remunerada e obrigatória ${ }^{85}$. A justificativa apresentada para esse indicador expressa a importância do trabalho para o Desenvolvimento Humano para além de seu aspecto da vulnerabilidade econômica, alcançando proveito à subjetividade humana ${ }^{86}$. Tal indicador não reapareceria, todavia, nos RDHs subsequentes.

O RDH de 2013 (“A Ascensão do Sul: Progresso Humano num Mundo Diversificado”) lança luzes ao Sul Global, notadamente às experiências de expansão do Desenvolvimento Humano, alavancadas por países que ostentaram crescimento econômico substancial, no início do século XXI. Esse RDH compreende o Trabalho Decente como resultante da ampliação das principais capacidades, nomeadamente alimentação, educação, saúde e qualificações ${ }^{87}$, alertando para uma exigência dessa evolução econômica: oferta de Trabalho Decente que seja compatível com o rápido crescimento dos países do Sul Global, sobre pena de conflagração civil $^{88}$.

No que tange à intervenção estatal, o RDH de 2013 reafirma posicionamentos anteriores contra a flexibilidade laboral, em razão de favorecer riscos ao Trabalho Decente, até mesmo porque leis sobre salário mínimo, proteção do emprego, limites da jornada de trabalho, segurança social e modelos contratuais seguros, tomadas em conjunto, auxiliam não processo de redução da desigualdade ${ }^{89}$. Ainda no campo do Estado, atuando na redução das desigualdades sociais, as experiências de Brasil e Índia são mencionadas como exemplos da época de locus de políticas públicas de transferência de renda conjugada com "programas de direito ao trabalho", medidas até então consideradas equivocadas ou ineficazes pelos tradicionais modelos de desenvolvimento ${ }^{90}$.

Intitulado "O Trabalho como Motor do Desenvolvimento Humano", o RDH de 2015 assume, finalmente, a importância do trabalho para a promoção do Desenvolvimento Humano, tratando, pela primeira vez, a expressão Trabalho Decente, em termos de conteúdo, de forma totalmente sintonizada com a concepção da OIT, bem como com os à época recém aprovados ODS e seu oitavo objetivo ${ }^{91}$.

85 PNUD. Relatório do Desenvolvimento Humano 2010: a verdadeira riqueza das nações: vias para o desenvolvimento humano. Nova Iorque: PNUD, 2010. p. 197-200. Disponível em: https://www.br.undp.org/content/brazil/pt/home/library/idh/relatorios-dedesenvolvimento-humano/relatorio-do-desenvolvimento-humano-200010.html. Acesso em: 18 dez. 2019.

86 PNUD. Relatório do Desenvolvimento Humano 2010: a verdadeira riqueza das nações: vias para o desenvolvimento humano. Nova Iorque: PNUD, 2010. p. 83. Disponível em: https://www.br.undp.org/content/brazil/pt/home/library/idh/relatorios-de-desenvolvimento-humano/relatorio-do-desenvolvimento-humano-200010.html. Acesso em: 18 dez. 2019.

87 PNUD. Relatório do Desenvolvimento Humano 2013: a ascensão do Sul: progresso humano num mundo diversificado. Nova Iorque: PNUD, 2013. p. iv. Disponível em: https://www.br.undp.org/content/brazil/pt/home/library/idh/relatorios-de-desenvolvimento-humano/relatorio-do-desenvolvimento-humano-200012.html. Acesso em: 18 dez. 2019.

88 PNUD. Relatório do Desenvolvimento Humano 2010: a verdadeira riqueza das nações: vias para o desenvolvimento humano. Nova Iorque: PNUD, 2010. p. 15 e 94. Na mesma linha de preocupação, o relatório elenca os riscos e oportunidades advindos do avanço das tecnologias da informação como facilitadores do comércio de serviços. PNUD. Relatório do Desenvolvimento Humano 2013: a ascensão do Sul: progresso humano num mundo diversificado. Nova Iorque: PNUD, 2013. p. 45-50. Disponível em: https:// www.br.undp.org/content/brazil/pt/home/library/idh/relatorios-de-desenvolvimento-humano/relatorio-do-desenvolvimentohumano-200012.html. Acesso em: 18 dez. 2019.

89 PNUD. Relatório do Desenvolvimento Humano 2013: a ascensão do Sul: progresso humano num mundo diversificado. Nova Iorque: PNUD, 2013. p. 53. Disponível em: https://www.br.undp.org/content/brazil/pt/home/library/idh/relatorios-de-desenvolvimento-humano/relatorio-do-desenvolvimento-humano-200012.html. Acesso em: 18 dez. 2019.

90 PNUD. Relatório do Desenvolvimento Humano 2013: a ascensão do Sul: progresso humano num mundo diversificado. Nova Iorque: PNUD, 2013. p. 86. Disponível em: https://www.br.undp.org/content/brazil/pt/home/library/idh/relatorios-de-desenvolvimento-humano/relatorio-do-desenvolvimento-humano-200012.html. Acesso em: 18 dez. 2019.

91 PNUD. Relatório do Desenvolvimento Humano 2015: o trabalho como motor do desenvolvimento humano. Nova Iorque: PNUD, 2015. p. 1. Disponível em: https://www.br.undp.org/content/brazil/pt/home/library/idh/relatorios-de-desenvolvimento-humano/relatorio-do-desenvolvimento-humano-200014.html. Acesso em: 12 dez. 2019. 
O RDH de 2015, dentro do marco teórico seniano, reconhece haver uma relação "sinérgica" entre Trabalho Decente e reforço das capacidades individuais e, por conseguinte, entre Trabalho Decente e Desenvolvimento Humano ${ }^{92}$, que autoriza concluir que o labor executado em circunstâncias indignas implica privações e, por isso, viola o processo de Desenvolvimento Humano, cuja promoção depende "da qualidade do trabalho, das condições do trabalho, do valor social do trabalho, etc" ${ }^{\prime 93}$.

Alinhando-se aos ODS, o RDH de 2015 abraça o conceito de "trabalho sustentável" como aquele que "promove o desenvolvimento humano, reduzindo e eliminando simultaneamente certas externalidades negativas que podem verificar-se em diferentes escalas geográficas e temporais" "94, de modo que o Desenvolvimento Sustentável depende do Trabalho Sustentável, ao mesmo tempo em que aquele tem implicações consideráveis para esse, inclusive quanto ao processo produtivo ${ }^{95}$.

Fala-se, ainda, em "bem-estar dos trabalhadores", vislumbrado ante direitos, benefícios, proteção social e combate às desigualdades, demandando, entre outras tantas medidas, proteção da liberdade e da ação sindical e ampliação do número de Estados comprometidos com as normas internacionais fundamentais de proteção do trabalho, notadamente as preceituadas pela OIT $^{96}$.

A série histórica dos RDHs permite perceber que, na senda pragmática dos estudos sobre Desenvolvimento Humano, a atividade laboral, conquanto tenha sido, pontualmente, tratada como uma liberdade básica, ligada à construção da subjetividade, sua abordagem como instrumento de acesso à renda é sobejamente mais recorrente. Será possível afirmar que há o mesmo tratamento pelas reflexões teóricas senianas?

\section{Trabalho Decente à luz do enfoque das capacidades}

Tal como percebido com os RDHs, as obras que compendiam cada uma das três fases do pensamento de Sen - Sobre Ética e Economia, Desenvolvimento como Liberdade e A Ideia de Justiça —, versam, apenas, incidentalmente sobre o papel do trabalho na expansão das liberdades. Um olhar para essas obras, conjugadas com passagens em artigos esparsos dedicados ao tema do trabalho, permite entrever que não há uma análise detida sobre o trabalho vis-à-vis as categorias fundamentais do enfoque das capacidades, como se vê ocorrer com a saúde, a educação e a participação democrática.

Não obstante, é possível encontrar pontuais afirmações e levar a efeito inferências sobre o labor em condições dignas como liberdade substantiva, juntamente à educação básica e os serviços de saúde ${ }^{97}$, para além de sua função instrumental de acesso à renda. A chave para a consideração do trabalho em condições

92 PNUD. Relatório do Desenvolvimento Humano 2015: o trabalho como motor do desenvolvimento humano. Nova Iorque: PNUD, 2015. p. iii e 1 e 4. Disponível em: https://www.br.undp.org/content/brazil/pt/home/library/idh/relatorios-de-desenvolvimentohumano/relatorio-do-desenvolvimento-humano-200014.html. Acesso em: 12 dez. 2019.

93 PNUD. Relatório do Desenvolvimento Humano 2015: o trabalho como motor do desenvolvimento humano. Nova Iorque: PNUD, 2015. p. 6-7 e 46-52. Disponível em: https://www.br.undp.org/content/brazil/pt/home/library/idh/relatorios-de-desenvolvimento-humano/relatorio-do-desenvolvimento-humano-200014.html. Acesso em: 12 dez. 2019.

94 PNUD. Relatório do Desenvolvimento Humano 2015: o trabalho como motor do desenvolvimento humano. Nova Iorque: PNUD, 2015. p. 42. Disponível em: https://www.br.undp.org/content/brazil/pt/home/library/idh/relatorios-de-desenvolvimento-humano/relatorio-do-desenvolvimento-humano-200014.html. Acesso em: 12 dez. 2019.

95 PNUD. Relatório do Desenvolvimento Humano 2015: o trabalho como motor do desenvolvimento humano. Nova Iorque: PNUD, 2015. p. 16-19, 150-152 e 155-159. Disponível em: https://www.br.undp.org/content/brazil/pt/home/library/idh/relatorios-dedesenvolvimento-humano/relatorio-do-desenvolvimento-humano-200014.html. Acesso em: 12 dez. 2019.

96 PNUD. Relatório do Desenvolvimento Humano 2015: o trabalho como motor do desenvolvimento humano. Nova Iorque: PNUD, 2015. p. 21-27. Disponível em: https://www.br.undp.org/content/brazil/pt/home/library/idh/relatorios-de-desenvolvimentohumano/relatorio-do-desenvolvimento-humano-200014.html. Acesso em: 12 dez. 2019.

97 "Fatores econômicos e sociais como educação básica, serviços elementares de saúde e emprego seguro são importantes não apenas por si mesmos, como pelo papel que podem desempenhar ao dar às pessoas a oportunidade de enfrentar o mundo com coragem e liberdade". SEN, Amartya. Desenvolvimento como liberdade. São Paulo: Companhia das Letras, 2010. p. 90. 
dignas como uma liberdade substantiva, para além do já citado reconhecimento pelo RDH de 2000, pode ser inferida com mais segurança do modo como Sen aborda os efeitos do desemprego:

se a perda de renda fosse tudo que o desemprego acarreta, ela poderia ser, em grande medida, suprimida - para os indivíduos envolvidos mediante auxílio-renda. [...] Se, porém, o desemprego tem outros efeitos graves sobre a vida dos indivíduos, causando privações de outros tipos, a melhora graças ao auxílio-renda seria, nessa medida, limitada. Há provas abundantes de que o desemprego tem efeitos abrangentes além da perda de renda, como dano psicológico, perda de motivação para o trabalho, perda de habilidade e autoconfiança, aumento de doenças e morbidez (e até mesmo de taxas de mortalidade), perturbação das relações familiares e da vida social, intensificação da exclusão social e acentuação de tensões raciais e das assimetrias entre os sexos ${ }^{98}$.

Fiel à natureza individualista/relativista do enfoque das capacidades, Sen dedica o ensaio Inequality, Unemployment and Contemporary Europe a uma análise comparativa da situação de desemprego em países europeus e nos EUA, para tanto assumindo como premissa que a variedade de efeitos nocivos do desemprego, do ponto de vista do exame macro das desigualdades, reclama atenção para o equívoco de se reduzir a desigualdade à mera desigualdade de renda, sendo fundamental devotar atenção para o locus em que se inserem as vítimas do desemprego, sobretudo no que tange à assistência social conferida pelo Estado para as pessoas desempregadas. Assim, a variedade e a intensidade dos efeitos do desemprego no impacto para a desigualdade irão depender, sobretudo, da forma como o Estado ampara (ou não) seus desempregados ${ }^{99}$.

Impossível olvidar, contudo, a recorrente preocupação com a inserção das pessoas no mercado e o trato do desemprego com base na perspectiva da renda enquanto fator de remoção de algumas privações aquelas suscetíveis ao ingresso da pessoa no mercado. Sob essa ótica, a força de trabalho, inexoravelmente, transmuta-se em mercadoria posta à transação e, por conseguinte, exposta aos abusos que tanto Smith quanto Sen reconhecem praticados pelo mercado, por mais que se tenha esforçado o pensador indiano em ressuscitar a vinculação entre ética e economia. Portanto, se, ao sentir de Sen, a liberdade de estar no mercado é crucial para o processo de expansão das capacidades, o é, outrossim, a proteção contra a sanha do capital, que há de vir, do Estado, no que se refere, em especial, à promoção das 5 liberdades instrumentais, com destaque (na área laboral), dentre elas, às facilidades econômicas, às oportunidades sociais e à segurança protetora.

O trabalho, assim contextualizado pelo arcabouço teórico seniano, pode significar, portanto, uma liberdade substantiva e instrumental, se desempenhado em condições dignas e aptas a expandir suas capacidades e conferir intitulamentos, mas também pode representar fator de privação e de pobreza, se desempenhado em condições precárias e indignas. A esse propósito, é possível compreender o Trabalho Decente como uma concepção que serve ao estabelecimento de um padrão globalmente aceito para a promoção, em termos coletivos (sociais), das condições de trabalho favorecedoras da expansão das capacidades individuais, portanto, do Desenvolvimento Humano e que, ao mesmo tempo, faça as vezes de paradigma para o exame da consonância de práticas privadas e públicas com o processo de desenvolvimento sustentável aplicado ao campo laboral.

\section{Trabalho Decente: comportamento ético, política pública ou direito?}

A influência do pensamento seniano na concepção do Trabalho Decente e nos desdobramentos da sua promoção pela OIT são manifestas, a começar pela proposital adoção de um conceito aberto e de uma

\footnotetext{
98 SEN, Amartya. Desenvolvimento como liberdade. São Paulo: Companhia das Letras, 2010. p. 129-130. Cada um dos citados efeitos deletérios do desemprego e outros mais experimentaram análise individualizada em SEN, Amartya. Inequality, unemployment and contemporary Europe. International Labour Review, Genebra, v. 136, n. 2, p. 155-171, 1997.

99 SEN, Amartya. Desenvolvimento como liberdade. São Paulo: Companhia das Letras, 2010. p. 161.
} 
ideia de conteúdo flexível, que se mostre adaptável às vicissitudes de cada nação ou grupo local disposto a promove-lo. Tal flexibilidade mostra-se perfeitamente harmônica com a subjetividade que permeia tanto o plano individual em que se constituem os sentidos das categorias "capacidades", "funcionamentos" e "agência" quanto o plano coletivo das deliberações acerca das liberdades prioritárias, para o qual se dirigem as reflexões de Sen sobre a Escolha Social.

A inspiração seniana da noção de Trabalho Decente pode ser entrevista, também e especialmente, nos quatro objetivos estratégicos para os quais convergem a sua promoção, pois aspiram estabelecer, cada qual, providências que contribuam para o enfrentamento das privações de liberdades substantivas e instrumentais tipicamente verificáveis na seara laboral, contemplando seus aspectos de oportunidade e processuais. A proteção dos direitos humanos nas relações laborais ${ }^{100}$, a geração de empregos com qualidade e a expansão da proteção social intentam intermediar, em múltiplas e específicas circunstâncias da venda da força de trabalho, o acesso fática e juridicamente protegido ao próprio mercado de trabalho, à saúde, à educação (inclusive para o trabalho) e à renda, enquanto o diálogo social, em conjunto com a liberdade sindical e a negociação coletiva, busca observar a preceituada participação política nos espaços normativos e de decisão.

Os objetivos estratégicos do Trabalho Decente dirigem-se mais claramente à ação estatal. Não por outro motivo, como visto, a adoção dessa concepção marca a decisão da OIT de pautar sua atuação pela busca de um enfoque integrado juntamente a outros atores internacionais, mas, principalmente, a seus Estados Membros, a partir da cooperação técnica voltada à confecção de programas nacionais de promoção do Trabalho Decente ${ }^{101}$.

Tal percepção permite, pois, que a natureza processual típica da promoção do Desenvolvimento Humano seja, também, adequada ao Trabalho Decente, obstando que quaisquer dessas expressões sejam tomadas por categorias de classificação de situações fáticas individualmente consideradas. Em outras palavras, a noção de Desenvolvimento Humano não existe para catalogar quais seres humanos são desenvolvidos e quais não o são, tampouco o Trabalho Decente não foi originariamente concebido para permitir que determinadas relações laborais sejam classificadas como decentes e, outras, por exclusão, indecentes. Esse tipo de classificação será plausível, apenas, se havido o reconhecimento das situações fáticas de privação constatadas em cada existência humana, como nas hipóteses de fome, desabrigo, analfabetismo (ou baixa escolaridade), exposição evitável a doenças e à mortalidade, desemprego, trabalho não remunerado ou mal remunerado, labor com exposição a riscos à vida e à segurança, desamparo estatal frente ao desemprego e à inaptidão para o trabalho, ausência de participação política na atuação sindical ou do sindicato em negociação coletiva etc.

Diante de sua natureza flexível e processual, bem como de sua finalidade promocional, pode-se afirmar que a concepção de Trabalho Decente foi forjada, primordialmente, para impulsionar políticas públicas nos níveis nacional, regional e local, com conformações peculiares pertinentes à conjuntura envolvida, tal como se percebe com a aferição do IDH pelo PNUD e as decorrentes atividades promocionais desse órgão internacional junto aos Estados.

Por outro lado, a ideia de Trabalho Decente, compreendida desde seus objetivos estratégicos, permite entrever um comportamento ético a ser observado no campo privado, sobretudo pelos atores do mercado que compram a força de trabalho. A observância dos direitos humanos trabalhistas preceituados pela Declaração da OIT sobre Princípios e Direitos Fundamentais no Trabalho de 1998 e pelas legislações nacionais, em si, é um comportamento ético desejável, nada obstando seja objeto de política pública, como fez questão de afirmar Sen, perante os representantes dos Estados Membros da OIT, reunidos na $87^{a}$ Conferência

\footnotetext{
100 Notadamente a liberdade sindical e o reconhecimento efetivo do direito de negociação coletiva, a eliminação de todas as formas de trabalho forçado ou obrigatório a abolição efetiva do trabalho infantil; e a eliminação da discriminação em matéria de emprego e ocupação.

101 ORGANIZACIÓN INTERNACIONAL DEL TRABAJO. Conferencia Internacional del Trabajo. 89a reúnion. Discusión Del Informe Del Presidente Del Consejo De Administración Y De La Memoria Del Director General. (Cont.). Ginebra: OIT, 2001. p 16. Disponível em: http://www.ilo.org/public/spanish/standards/relm/ilc/ilc89/pdf/pr-5s4.pdf. Acesso em: 19 dez. 2019.
} 
Internacional do Trabalho ${ }^{102}$. O mesmo se aplica à geração de empregos de qualidade (não precários), ao financiamento da assistência social do Estado e à oportunização do diálogo social.

Diante dessa perspectiva, políticas públicas de Estado para o Trabalho Decente suscitam também a necessidade de medidas que habilitem o aparato estatal a fomentar e implementar comportamentos público e privado compatíveis com o processo de promoção de que se cuida, reprovando e sancionando o que houver em sentido contrário. No que se refere aos atores privados, há de se rememorar a vigência da Declaração Tripartite de Princípios sobre Empresas Multinacionais e Política Social de 2002, recentemente atualizada, com vistas a compatibilizar-se com os Princípios Orientadores para Empresas e Direitos Humanos da ONU (2011) e a Agenda 2030 (2015). É nesse ponto que faz sentido pensar o Trabalho Decente, para além de um comportamento ético ou de diretrizes para políticas públicas, como bem juridicamente tutelado, dotando-o da prerrogativa de ser institucionalmente reivindicado, sem o que estar-se-á negando ao indivíduo a possibilidade de experimentar os intitulamentos e as contribuições em favor da expansão de suas capacidades, a que se propôs a OIT, quando lançou mão da ideia.

O discurso de Sen à $87^{a}$ Conferência Internacional do Trabalho, em 1999, não abordou a aplicação do enfoque das capacidades às relações de trabalho, mas dedicou-se, em sua maior medida, a saudar a intenção de estabelecimento de um padrão internacional de ações para o enfrentamento das mazelas sociais advindas da exploração da força de trabalho. Empreendendo argumentação em prol da proteção de direitos humanos trabalhistas, mesmo aqueles não contemplados em norma positiva, a fala de Sen a OIT — que, na ocasião, abraçava a concepção de Trabalho Decente — retomou alegação recorrente, apoiada na noção kantiana de obrigações imperfeitas, no sentido de haver direitos que, por característica, não permitem que sejam vislumbradas todas as obrigações dele decorrentes, assim como todo o conjunto de obrigados à sua observância. Nessa linha, há direitos que, prima facie, têm aptidão para obrigar todas as situações e todos aqueles que possam, de algum modo, contribuir para a consecução ou violação, o que se define casuisticamente ${ }^{103}$.

A obrigação imperfeita de Kant afigura-se adequada, em particular, para compreensão do alcance e da tutela de direitos de caráter processual, como o direito ao desenvolvimento, o que torna plausível falar-se em um direito ao Trabalho Decente, que suscita obrigações imperfeitas, capazes de estabelecer a obrigação jurídica do Estado de adotar ações promocionais e também obrigações do Estado, do mercado e dos demais particulares de se comportem conforme os preceitos éticos derivados dos quatro objetivos estratégicos que convergem para o Trabalho Decente. Assim, corresponde ao direito ao Trabalho Decente a possibilidade de sua reivindicação em face de decisões estatais, inclusive acerca de políticas públicas, que porventura vão de encontro a quaisquer dos objetivos estratégicos que conformam a realização do direito. Quanto ao ponto, não é objeto deste estudo a longeva controvérsia sobre os limites da atuação judicial em face das políticas públicas, mas, ao menos, a intervenção judicial de menor intensidade, consistente em obstar os efeitos da decisão administrativa antijurídica, há de ser admitida como consequência lógica da tomada do direito em questão ${ }^{104}$.

A ausência de um tratado internacional específico sobre Trabalho Decente não impede sua cogência em face dos Estados Membros da OIT — como é o caso do Brasil —, na medida em que as normas internacionais vinculantes não se reduzem à figura dos tratados internacionais, com isso tendo seus efeitos condi-

102 SEN, Amartya. Work and rights. International Labour Review, Genebra, v. 139, n. 2, p. 123-124, 2000.

103 SEN, Amartya. Work and rights. International Labour Review, Genebra, v. 139, n. 2, p. 124-125, 2000. Para uma análise aplicada ao direito ao desenvolvimento da concepção kantiana de obrigações imperfeitas utilizada por Sen, cf. SENGUPTA, Arjun. On the Theory and Practice of the Right to Development. Human Rights Quarterly, Baltimore, v. 24, n. 4, p. 837-889, 2002. p. 843-846.

104 Já em relação a relações privadas individualmente consideradas, a despeito de a concepção de Trabalho Decente não haver sido, como sustentado, concebida para ensejar direitos subjetivos de uma pessoa que vende sua força de trabalho em face de seu contratante, isso não significa que, judicialmente, tal condição seja de reconhecimento inviável. A respeito, confira-se a proposta formulada em BELTRAMELLI NETO, Silvio; VOLTANI, Julia de Carvalho. Investigação histórica do conteúdo da concepção de Trabalho Decente no âmbito da OIT e uma análise de sua justiciabilidade. Revista de Direito Internacional, Brasília, v. 16, n. 1, p. 166185, 2019. p. 176-182. 
cionados, exclusivamente, ao consentimento estatal manifestado na forma de ratificação.

Essa vetusta compreensão das normas internacionais encontra-se, como explica Cançado Trindade ${ }^{105}$, completamente superada, no que tange aos direitos humanos, pelo adensamento da força normativa vinculante de deliberações alcançadas por consenso da comunidade internacional, materializado em resoluções e declarações aprovadas em assembleia e não sujeitas à posterior ratificação, dotadas de efeito e legitimidade pela democrática construção de uma opinio juris coletiva (expressão de uma "consciência jurídica universal”). Desde essa compreensão, não parece demasiado classificar-se o Trabalho Decente como norma imperativa, inderrogável e vinculante (norma de jus cogens) ${ }^{106}$, que obriga independentemente de consentimento estatal formalizado por posterior e individual ratificação, até mesmo porque assim já estabeleceu a OIT deve ser considerada a Declaração da OIT sobre Princípios e Direitos Fundamentais no Trabalho de 1998 (estruturante da concepção de Trabalho Decente) em relação a todos os seus Estados Membros.

Igualmente preservada está a aplicabilidade nacional da norma que abriga o direito ao Trabalho Decente, em decorrência da sua integração fundamentada nos arts. $4^{\circ}$, II, e $5^{\circ}, \mathbb{} 2^{\circ}$, da Constituição Federal.

Em conclusão, o Trabalho Decente contempla as dimensões associadas do comportamento ético, da política pública e do bem juridicamente tutelado (um direito), estabelecidas em ordem a favorecer o processo de Desenvolvimento Humano nas relações de trabalho, colocado em marcha com a expansão de liberdades e remoção de privações. Ao modo de Sen, o Trabalho Decente deve ser adotado como um comportamento ético pelo Estado e pelos particulares, apto a suscitar políticas públicas, mas que, sem embargo, admita reivindicação dentro da técnica jurídica.

\section{Considerações finais}

Recém completados 100 anos do advento da OIT e 20 anos da adoção da concepção de Trabalho Decente, ainda muito se discute sobre o alcance das ações e dos compromissos internacionais e nacionais correlatos à sua promoção.

Nascida para marcar uma virada no modo de atuação da OIT quanto à consecução de sua finalidade regulatória da tensão capital-trabalho, a noção de Trabalho Decente, a despeito de sua fluidez conceitual, espraiou-se como sinônimo de "mínimo civilizatório" das relações de trabalho — do que é exemplo sua contemplação específica pela Agenda 2030 —, conquanto, ainda, muitas incertezas, críticas e até indiferenças a acometam.

Particularmente no Brasil, o termo Trabalho Decente aparenta suscitar adesão pela maioria das pessoas, mas, no mais das vezes, sob o signo de esparsas compreensões intuitivas e até coloquiais (inclusive no contexto jurídico), sendo certo que a ausência de uma melhor delimitação de seu conteúdo e de seu escopo maculam suas possibilidades de eficaz promoção.

Procurou-se demonstrar que o Trabalho Decente é uma concepção multidimensional e de natureza processual, que contempla comportamento ético, políticas públicas e tutela jurídica e que se justifica pelo intento de contribuir para o avanço do Desenvolvimento Humano, a partir do campo das relações de trabalho. Para tanto, sistematizou-se o pensamento econômico-filosófico de Amartya Sen, artífice da ideia de Desenvolvimento Humano e admitida inspiração da noção de Trabalho Decente, com vistas a demonstrar

105 TRINDADE, A. A. Cançado. A bumanizaçãa do direito internacional. Belo Horizonte: Del Rey, 2006. p. 76-96.

106 As normas imperativas estão contempladas no art. 53 da Convenção de Viena sobre o Direito dos Tratados, promulgada, no Brasil, pelo Decreto n. ${ }^{\circ}$ 7.030/2009, a saber: "É nulo um tratado que, no momento de sua conclusão, conflite com uma norma imperativa de Direito Internacional geral. Para os fins da presente Convenção, uma norma imperativa de Direito Internacional geral é uma norma aceita e reconhecida pela comunidade internacional dos Estados como um todo, como norma da qual nenhuma derrogação é permitida e que só pode ser modificada por norma ulterior de Direito Internacional geral da mesma natureza". 
que, à luz de seu marco teórico, o Trabalho Decente deve ser compreendido como uma concepção a serviço da promoção do trabalho como liberdade (compreendida ao modo seniano), como fator de expansão de capacidades e como meio para intitulamentos.

Não coube às reflexões expostas fazer juízo crítico sobre a teoria estudada e sobre o Trabalho Decente como objeto de exame, conquanto a crítica caiba, em diversos aspectos, como, de fato, vem sendo feito, notadamente no âmbito acadêmico. A proposta foi, desde o início, uma análise do Trabalho Decente enquanto iniciativa internacional mediadora e regulatória da tensão capital-trabalho (portanto não emancipatória) e assim foi feito. O mote, contudo, nos tempos atuais, reclama abordagem para além do interesse acadêmico.

É que, em tempos ultraliberais de cooptação de Estado pelo mercado, de desemprego estrutural agravado por crises econômicas mundiais, extinção de direitos sociais e reestruturação da morfologia do trabalho, delineada pelo capital financeiro globalizado, pelas cadeias globais de valor e pela revolução tecnológica informacional, não parece exagero considerar que a promoção do Trabalho Decente está a fazer face ao seu maior desafio. Um desafio que coloca em xeque sua própria viabilidade, ao menos para aqueles que não a negam à partida.

Nesse contexto alarmante, reflexões mais recorrentes e acuradas sobre as possibilidades e finalidades do Trabalho Decente se impõem como condição de perpetuação da ideia, sem deformações.

\section{Referências}

ALKIRE, Sabina; DENEULIN, Séverine. An introduction to the buman development and capability approach. London: Earthscan, 2009. Disponível em: http:// citeseerx.ist.psu.edu/viewdoc/download?doi=10.1.1.383.623 $1 \&$ rep=rep1\&type=pdf. Acesso em: 17 dez. 2019.

AMARO, Rogério Roque. Desenvolvimento ou Pós-Desenvolvimento? Des-Envolvimento e... Noflay! Cadernos de Estudos Africanos, Lisboa, n. 34, p. 75-111, jul/dez. 2017. Disponível em: http://www.scielo.mec.pt/ scielo.php?script=sci_abstract\&pid=S1645-37942017000200005\&lng=en\&nrm=iso\&tlng=pt. Acesso em: 10 dez. 2019.

AMARO, Rogério Roque. Desenvolvimento: um conceito ultrapassado ou em renovação? Da teoria à prática e da prática à teoria. Cadernos de Estudos Africanos, Lisboa, n. 4, p. 40-60, jan/jul. 2003. Disponível em: https://revistas.rcaap.pt/cea/article/view/8659. Acesso 12 nov. 2019.

ARAUJO, Luiz Bernardo Leite; CREDER, Fábio dos Santos. Ética, economia e justiça: a escolha social no pensamento de Sen e Smith. Dois Pontos, Curitiba, v. 10, n. 1, p. 103-126, abr. 2013. Disponível em: https:// revistas.ufpr.br/doispontos/article/view/30654. Acesso em: 17 dez. 2019.

BELTRAMELLI NETO, Silvio; VOLTANI, Julia de Carvalho. Investigação histórica do conteúdo da concepção de Trabalho Decente no âmbito da OIT e uma análise de sua justiciabilidade. Revista de Direito Internacional, Brasília, v. 16, n. 1, p. 166-185, 2019. Disponível em: https://www.publicacoesacademicas.uniceub. br/rdi/article/view/5900. Acesso em: 10 dez. 2019.

BELTRAMELLI NETO, Silvio; BONAMIM, Isadora Rezende; VOLTANI, Julia de Carvalho. Trabalho Decente segundo a OIT: uma concepção democrática? Análise crítica à luz da teoria do contrato social. Revista Eletrônica do Curso de Direito da UFSM, v. 14, n. 1, p. 1-36, 2019. Disponível em: https://periodicos. ufsm.br/revistadireito/article/view/33853. Acesso em: 10 dez. 2019.

BENTES, Natalia Mascarenhas Simões; BRÍGIDA, Yasmin Salgado Santa. Vinculação dos direitos econômicos, sociais e culturais: uma discussão do desenvolvimento humano com base no conceito de Amartya Sen sobre o mínimo existencial. Revista de Direito Internacional, Brasilia, v. 15, n. 3, p. 99-121, 2018. Disponível: 
https://www.publicacoesacademicas.uniceub.br/rdi/article/view/5596. Acesso em: 10 dez. 2019.

MACHADO, Raimar Rodrigues. O trabalho humano frente à ideia de liberdade. In: COSTA, M. M.; LEAL, M. C. H. (orgs.). Direitos sociais e políticas púbicas: desafios contemporâneos. Santa Cruz do Sul: EDUNISC, 2012. p. 204-280.

MORAES, M.; DIEHL, R. O papel da organização internacional do trabalho na promoção do trabalho decente: diálogos com Amartya Sen. Revista Prolegómenos Derechos y Valores, Bogotá, v. 19, n. 38, p. 97-108, jul./dez. 2016.

MUNIZ, Veyzon Campos. Desenvolvimento humano sustentável e erradicação da pobreza extrema. Revista Brasileira de Políticas Públicas, Brasília, v. 6, n. 1, p. 175-191, jan./jul. 2016. Disponível em: https://www.publicacoesacademicas.uniceub.br/RBPP/article/view/3481. Acesso em: 10 mar. 2020.

NASCIMENTO, Elimar Pinheiro do. Trajetória da sustentabilidade: do ambiental ao social, do social ao econômico. Estudos Avançados, São Paulo, v. 26, n. 74, p. 51-64, 2012. Disponível em: http://www.scielo.br/ scielo.php?pid=S0103-40142012000100005\&script=sci_abstract\&tlng=pt. Acesso em: 10 dez. 2019.

ORGANIZAÇÃO INTERNACIONAL DO TRABALHO. História da OIT. Disponível em: http://www. oitbrasil.org.br/content/hist\%C3\%B3ria. Acesso em: 29 out. 2019.

ORGANIZAÇÃO INTERNACIONAL DO TRABALHO. Declaração da OIT sobre os Princípios e Direitos Fundamentais no Trabalho. Genebra, 1998. Disponível em: http://www.ilo.org/public/english/standards/declaration/declaration_portuguese.pdf. Acesso em: 16 dez. 2019.

ORGANIZACIÓN INTERNACIONAL DEL TRABAJO. Conferencia Internacional Del Trabajo. 89a reúnion. Discusión Del Informe Del Presidente Del Consejo De Administración Y De La Memoria Del Director General (Cont.). Ginebra: OIT, 2001. Disponível em: http://www.ilo.org/public/spanish/standards/relm/ilc/ilc89/ pdf/pr-5s4.pdf. Acesso em: 19 dez. 2019.

PNUD. Relatório do Desenvolvimento Humano 2015: O Trabalho como Motor do Desenvolvimento Humano. Nova Iorque: PNUD, 2015. Disponível em: https://www.br.undp.org/content/brazil/pt/home/library/ $\mathrm{idh} /$ relatorios-de-desenvolvimento-humano/relatorio-do-desenvolvimento-humano-200014.html. Acesso em: 12 dez. 2019.

PNUD. Relatório do Desenvolvimento Humano 2013: A Ascensão do Sul: Progresso Humano num Mundo Diversificado. Nova Iorque: PNUD, 2013. Disponível em: https://www.br.undp.org/content/brazil/pt/home/ library/idh/relatorios-de-desenvolvimento-humano/relatorio-do-desenvolvimento-humano-200012.html. Acesso em: 18 dez. 2019.

PNUD. Relatório do Desenvolvimento Humano 2010: A Verdadeira Riqueza das Nações: Vias para o Desenvolvimento Humano. Nova Iorque: PNUD, 2010. Disponível em: https://www.br.undp.org/content/brazil/pt/home/library/idh/relatorios-de-desenvolvimento-humano/relatorio-do-desenvolvimento-humano-200010.html. Acesso em: 18 dez. 2019.

PNUD. Relatório do Desenvolvimento Humano 2001: Fazendo as novas tecnologias trabalhar para o desenvolvimento humano. Nova Iorque: PNUD, 2001. Disponível em: https://www.br.undp.org/content/brazil/pt/ home/library/idh/relatorios-de-desenvolvimento-humano/relatorio-do-desenvolvimento-humano-20001. html. Acesso em: 18 dez. 2019.

ROBEYNS, Ingrid. An unworkable idea or a promising alternative? Sen's capability approach re-examined. Discussion Paper Series, Katholieke Universiteit Leuven. Faculty of Economics and Applied Economics, p. 1-33, 2000. Disponível em: https:// feb.kuleuven.be/drc/Economics/research/dps-papers/dps00/ dps0030.pdf. Acesso em: 17 dez. 2019.

SACHS, Ignacy. O desenvolvimento enquanto apropriação dos direitos humanos. Estudos Avançados, São 
Paulo, v. 12, n. 33, p. 149-156, 1998. Disponível em: http://www.scielo.br/pdf/ea/v12n33/v12n33a11.pdf. Acesso em: 19 nov. 2019.

SANCHEZ GARRIDO, Pablo. Raices intelectuales de Amartya Sen: Aristóteles, Adam Smith y Karl Marx. Madrid: Centro de Estudos Políticos y Constitucionales, 2008.

SANTOS, Moacir José dos; CARNIELLO, Monica Franchi. História do desenvolvimento: limites de um campo de pesquisa. Revista Brasileira de Gestão e Desenvolvimento Regional, Taubaté, v. 10, n. 3, p. 67-88, 2014. Disponível em: https://www.rbgdr.net/revista/index.php/rbgdr/article/view/1472. Acesso em: 12 nov. 2019.

SEN, Amartya. Desenvolvimento como liberdade. São Paulo: Companhia das Letras, 2010.

SEN, Amartya. Sobre ética e economia. São Paulo: Companhia das Letras, 1999.

SEN, Amartya. Human Rights and Capabilities. Journal of Human Development, v. 6, n. 2, p. 151-166, jul. 2005.

SEN, Amartya. Work and rights. International Labour Review, Genebra, v. 139, n. 2, p. 119-128, 2000.

SEN, Amartya. Global justice: beyond international equity. In: KAUL, Inge et al. (eds.). Global Public Goods: International Cooperation in the 21st Century. New York; Oxford: Oxford University Press, 1999. p. 116125.

SEN, Amartya. The Possibility of Social Choice. The American Economic Review, Pittsburgh, v. 89, n. 3, p. 349378, 1999.

SEN, Amartya. Inequality, unemployment and contemporary Europe. International Labour Review, Genebra, v. 136, n. 2, p. 155-171, 1997.

SEN, Amartya. Equality of What? The Tanner lecture on buman values, Stanford, v. 1, p. 195-220, 1980.

SENGUPTA, Arjun. On the Theory and Practice of the Right to Development. Human Rights Quarterly, Baltimore, v. 24, n. 4, p. 837-889, 2002. Disponível em: https://muse.jhu.edu/article/13865. Acesso em: 11 dez. 2019.

TRINDADE, A. A. Cançado. A bumanização do direito internacional. Belo Horizonte: Del Rey, 2006.

TRUBEK, David. Para uma teoria social do direito: um ensaio sobre o estudo do direito e desenvolvimento. In: RODRIGUEZ, José Rodrigo (org.). O Novo Direito e Desenvolvimento: presente, passado e futuro. São Paulo: Saraiva, 2009. p. 51-122.

UNDP. Human Development Report 2019: Beyond income, beyond averages, beyond today: Inequalities in human development in the 21st century. New York: UNDP, 2019. Disponível em: http://hdr.undp.org/sites/ default/files/hdr2019.pdf. Acesso em: 18 dez. 2019.

UNDP. Human Development Report 2000: Human Rights and Human Development. New York: UNDP, 2000. Disponível em: https://www.br.undp.org/content/brazil/pt/home/library/idh/relatorios-de-desenvolvimento-humano/relatorio-do-desenvolvimento-humano-2000.html. Acesso em: 18 dez. 2019.

VAN DAELE, Jasmien. The International Labour Organization (ILO) in Past and Present Research. International Review of Social History, Cambridge, v. 53, n. 3, p. 485-511, dez. 2008.

ZEIFERT, Anna Paula Bagetti; STURZA, Janaína Machado Sturza. As políticas públicas e a promoção da dignidade: uma abordagem norteada pelas capacidades (capabilities approch) propostas por Martha Nussbaum. Revista Brasileira de Políticas Públicas, Brasilia, v. 9, n. 1, p. 114-126, abr. 2019. Disponível em: https:// www.publicacoesacademicas.uniceub.br/RBPP/article/view/5894. Acesso em: 08 mar. 2020. 
Para publicar na revista Brasileira de Políticas Públicas, acesse o endereço eletrônico www.rbpp.uniceub.br

Observe as normas de publicação, para facilitar e agilizar o trabalho de edição. 